\title{
SOLUBILIZAÇÃO DE FOSFATO NATURAL EM RELAÇÃO A CALAGEM E DIFERENCA DE APROVEITAMENTO POR VARIEDADES DE SOJA.
}

JOĀO BAPTISTA PALHANO

Orientador: PROF. DR. TOSHIAKI KINJO

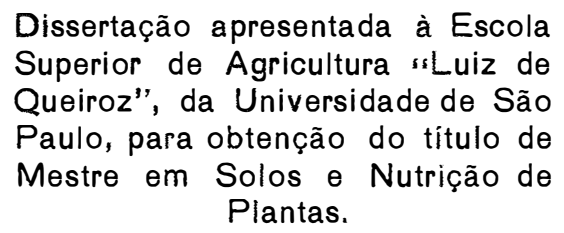

PIR A C ICABA

Estado de São Paulo - Brasil

Março - 1980 
A memōria de meu PAI.

A minha esposa Neusa, pelo incentivo e compreensão.

Ao meu filho Marcelo. 


\section{AQRADECIMENTOS}

Agradeço às seguintes pessoas e instituições que direta ou indiretamente colaboraram na execução deste trạ balho:

- Prof. Dr. Toshiaki Kinjo.

- Dr. Hipölito A. A. Mascarenhas.

- Prof. Dr. Décio Barbin.

- Prof. Dr. Ronaldo Ivan Silveira.

- Colegas Jaime A. de Almeida e Helenita Antonio.

- Sr. Angelo Smaniotto.

- Embrapa, através do Centro Nacional de Pesquisa de Soja.

- Departamento de Solos, Geologia e Fertilizantes, da Escola Superior de Agricultura "Luiz de Queiroz". 


\section{N D I C E}

Pàgina

I. RESUMO

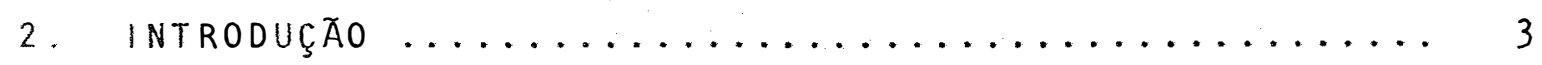

3. Revisão de literatura $\ldots \ldots \ldots \ldots \ldots \ldots \ldots \ldots \ldots \ldots \ldots \ldots$

3.1. Estudos gerais sobre o fósforo $\ldots \ldots \ldots \ldots \ldots 6$

3.2. Solubilidade e solubilização dos fosfatos.... 8

3.3. Extratores químicos de fósforo ........... 12

3.4. Efeito de fosfatos na cultura da soja....... 15

3.5. Diferenças entre variedades ............ 17

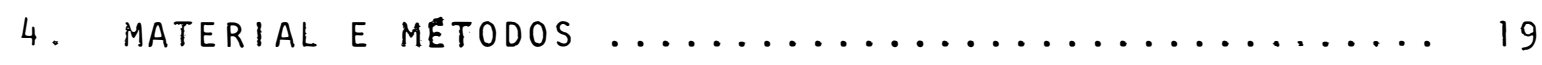

4.1. Seleção preliminar do solo ............... 19

4.2. Coleta do solo, preparo e caracterização física e química ......................... 20

4.3. Esquema de tratamentos e delineamento experi -

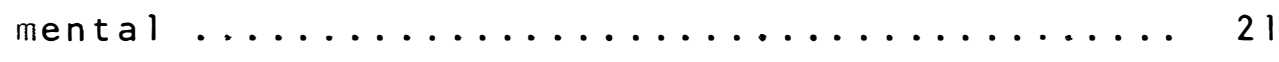

4.4. Determinação da quantidade de $\mathrm{Ca}(\mathrm{OH})_{2}$ e aplica

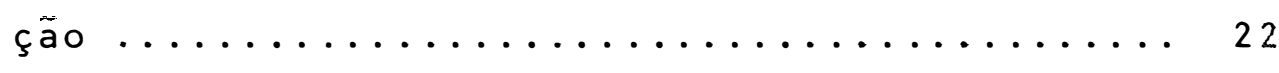

4.5. Preparo e aplicação dos fosfatos .......... 23

4.6. Local e início de execução .............. 23 
4.7. Experimento em casa de vegetaçăo .......... 24

4.8. Amostragens e anälises do fösforo do solo.... 25

4.9. Anälises químicas de tecido .............. 26

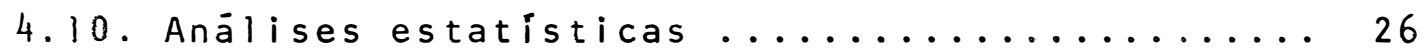

5. RESULTADOS E DISCUSSÃO .................... 27

5.1. Avaliações biolögicas ................... 27

5.1.1. Avaliação dos tratamentos de solo sobre algumas características vegetais.. 27

5.1 .1 .1$. Altura das plantas ............. 27

5.1 .1 .2 . Nümero de internódios .......... 28

5.1 .1 .3$. Peso de folhas $\ldots \ldots \ldots \ldots \ldots 28$

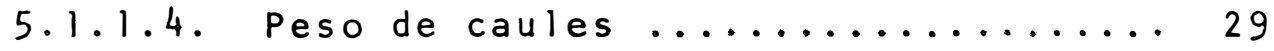

5.1.1.5. Peso de raízes ................. 29

5.1.2. Comportamento, entre variedades, algumas caracteristicas vegetais ...... 31

5.1.2.1. Altura de plantas ................31

5.1.2.2. Nümero de internödios .........4 4

$5.1 .2 .3 . \quad$ Peso de folhas ..............4 4

5.1 .2 .4 . Peso de caules ...............4 41

$5.1 .2 .5 . \quad$ Peso de raizes $\ldots \ldots \ldots \ldots \ldots \ldots \ldots$

5.2. Avaliações químicas .................. 43

5.2.1. Avaliação dos tratamentos de solo sobre os teores de fósforo .......... 43 
Pàgina

5.2.1.1. Teor de fösforo contido na parte aẹ rea vegetal $\ldots \ldots \ldots \ldots \ldots \ldots \ldots \ldots$

5.2.1.2. Fösforo do solo aos 30 dias de incu bас̧а̃o $\ldots \ldots \ldots \ldots \ldots \ldots \ldots$

5.2.1.3. Fósforo do solo aos 240 dias da incubação .................. 52

5.2.2. Comparação entre variedades ....... 52

5.2.3. Comparação entre extratores ....... 53

5.2.3.1. Fósforo do solo aos 30 dias de incu bас̧а̃o .................... 53

5.2.3.2. Fösforo do solo aos 240 dias de incubação ................... 56

5.3. Estudo da correlação entre extratores e produção de matēria seca ..................... 56

5.3.1. Matēria seca da parte aērea ....... 56

5.3.2. Matēria seca radicular .......... 57

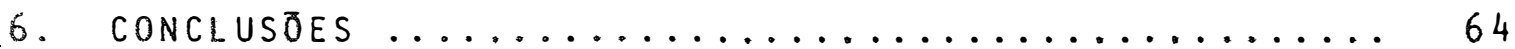

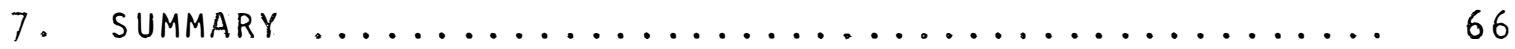

8. LITERATURA CITAdA ...................... 68 APENDICE 
1. RESUMO

Foi conduzido um experimento em casa de vegetação, com os objetivos: a) Estudar a diferença de capacidade de absorção de fósforo por variedades de soja (Glycine max (L.) Merril). b) Comparar a eficiência do fornecimento de $P$ às plantas ao se usar fosfato natural (F. Alvorada) e fosfato solúvel (fosfato monocálcico). c) Verificar a influência da acidez na solubilização do fosfato natural. d) Testar os seguintes extratores de fósforo, Mehlich, Bray 2 e $01 s e n$ quanto à capacidade de melhor se correlacionar com a produção vegetal de matéria seca.

o trabalho foi conduzido em um solo Podzólico Vermelho Amarelo, variação Piracicaba, Sërie Godinhos (PVA), on de se usou os seguintes tratamentos: fosfato monocálcico ( $T_{\mathrm{l}}$ ) Fosfato Alvorada $\left(T_{2}\right)$ e Testemunha $\left(T_{3}\right)$ incubados em $\mathrm{pH} 6,5$ e Fosfato Monocálcico $\left(T_{4}\right)$, Fosfato Alvorada (T5) e Testemunha (T6) incubados em pH 5,0 com correção imediata para o plantio. 
As variedades de soja estudadas foram: Bragg ( $\left.V_{1}\right)$, Paranä $\left(V_{2}\right)$ e Santa Rosa $\left(V_{3}\right)$ e o estudo com extratores de fósforo foi com os métodos de Mehlich, Bray 2 e 01 sen (modificado).

Alēm das avaliações químicas nas plantas e no solo procedeu-se tambēm avaliações biolögicas através de: altu ra de plantas, nümero de internódios, peso de caules, peso de folhas e peso do sistema radicular aos 62 dias apōs a emergên cia.

os resultados obtidos permitiram as seguintes conclusões para as condições deste trabalho:

- A variedade Paraná é mais sensível a fösforo do que as demais estudadas.

- o fosfato Alvorada apresenta menor eficiên cia no fornecimento de $P$ às plantas do que o fosfato monocálcico.

- A acidez do solo exerce influência no aumeñ to da solubilização do fosfato Alvorada.

- 0 mëtodo de 01 sen (modificado) apresenta as melhores correlações com a produção vegetal de matēria seca. 


\section{INTRODUÇAO}

o fösforo é um elemento essencial às plantas, e assim sendo é insubstituível nas suas funçöes dentro do vege tal, pois participa dos chamados compostos ricos em energia sendo o mais comum o trifosfato de adenosina, ATP.

A cíclagem do fósforo na natureza não è tão eficiente quanto as do $\mathrm{Co}_{2}$ e $\mathrm{N}_{2}$, estimando-se perdas anuais de 3,5 milhões de toneladas do elemento que se deposita no fundo do mar, Cole (1958) citado por EPSTEIN (1975) e o seu retorno atravês do guano de aves marinhas e dos peixes ë relativamente muito pequena.

As exploraçōes agrícolas em äreas pobres em fósforo disponivel, exigem a colocação deste através de suf cientes adubaçōes para complementar o fornecimento às plantas. A partir de 1967 o consumo de adubos no Brasil sofreu um elevado incremento, superando com larga margem a taxa média mundial, ANDA (1975). 
Evidentemente vários fatores contribuiram para esta situação e, sem dúvida alguma, a cultura da soja (Gly cine max (L.) Merril) acha-se engajada neste processo, haja visto que quando o cultivo se dá em condições de baixa dispon! bilidade de $P$ são amplas as perspectivas de resposta à fertil! zação fosfatada.

A prática mais usual entre os agricultores brasileiros, consiste primeiramente em se corrigir o pH para posterior adubação fosfatada, todavia, existem resultados expe rimentais indicando melhor eficiència dos fosfatos naturais quando antecedem por certo tempo a calagem.

Existem evidencias de que as variedades se comportam distintamente quanto a reação às adubações fosfatadas, sendo que as fontes de fósforo e as condições de acidez de solo em que são aplicadas tambëm reagem de formas diferentes.

Trabalhos recentes de NOVAIS e KAMPRATH(1979) que abordam o estudo com extratores quimicos de fósforo destacam uma marcante diferença extrativa de $P$ entre os mesmos e, muitas vezes, um método de anälise para fósforo pode mostrarse ineficiente para prever as necessidades de fertilização.

Este confunto de situações sugeriu que se conduzisse um experimento em casa de vegetação, visando: a) in vestigar possiveis diferenças entre as variedades de soja; Bragg, Paranä e Santa Rosa quanto à capacidade de absorção de 
5

fósforo via radicular. b) Comparar a eficiencia de fornecimento de $P$ às plantas através do uso de fosfato natural (Alvorada) e fosfato sólúvel (fosfato monocálcico). c) Verificar a influência do grau de acidez do solo na solubilização do fosfato na tural. d) Testar três métodos de extração, Mehlich, Bray 2 e olsen para identificar qual deles oferece as melhores correlações com a produção vegetal de matéria seca. 


\section{REVISAOO DE LITERATURA}

\subsection{Estudos gerais sobre o fösforo}

Apesar de ser amplamente estudado, este elemento ainda não ë bem compreendido em determinadas situaçōes de relacionamento solo-planta. o comportamento deste elemento nos solos está condicionado a uma série de fatores, e um fator i soladamente pode exercer influências distintas dependendo da situação em que se encontra. Pode-se citar o trabalho de HORTENSTINE (1966) que estuda a fixação deste elemento em solos americanos, e demonstra que a calagem progressiva causou um aumento linear na capacidade de fixação. Em outras condições e em outros solos pode-se ter um aumento na disponibili dade de $P$, como mostram os resultados obtidos por MASCARENHAS et. alii (1966).

VOLKWEISS e Van RAIJ (1977) abordando alguns aspectos sobre a disponibilidade e retenção de fösforo nos so- 
los, consideram que os teores totais deste elemento estão contidos na faixa de 100 a 2.000 ppm. Geralmente se apresenta como componente integrante de compostos sölidos, orgâncios e inor gânicos pouco solüveis ( $P-s o ̈ l i d o)$ e apenas uma pequena fração dissolvida em solução ( $P$-solução). Destacaram os autores o räpido equilibrio que ocorre entre certa quantidade do p - sólido com o p-solução. A porção de fósforo envolvida neste processo e que sai das partes sólidas do solo é denominada p-Lábil. Em solos ácidos, o fósforo inorgânico se encontra formando compos tos principais como: $\mathrm{Fe}(\mathrm{OH})_{2} \mathrm{H}_{2} \mathrm{PO}_{4}$, Al $(\mathrm{OH})_{2} \mathrm{H}_{2} \mathrm{PO}_{4}$ e comple xos de superficie ligados ao Fe e ao Al.

MALAVOLTA (1976) considera que as perdas por lavagem nos solos devem ser muito pequenas, pois além da baixa concentração de $P$ na solução dos solos em geral, a fixação se encarrega de evitar perdas expressivas desta natureza.0 ele mento é basicamente absorvido pelas plantas na forma de $\mathrm{H}_{2} \mathrm{PO}_{4}^{-}$ pelo processo de difusão na sua quase totalidade, Barber e 01son (1968) citados por MALAVOLTA (1976) atribuindo este autor uma dependência direta da superficie radicular neste processo.

- papel fundamental do fósforo na vida da planta trata-se da sua participação em compostos energéticos, embora alguns autores como HANSON (1979) admitem que não se reconhece com muito detalhe as implicaçōes funcionais do elemento na planta. 


\subsection{Solubilidade e solubilização dos fosfatos}

Francis (1965) citado por LARSEN (1967) descreve a seguinte equação que mostra o efeito do $H^{+}$na solubil zação da hidroxiapatita:

$$
\begin{array}{r}
\mathrm{Ca}_{10}\left(\mathrm{PO}_{4}\right)_{6}(\mathrm{OH})_{2}+8 \mathrm{H}^{+} \rightarrow 10 \mathrm{Ca}^{2+}+6 \mathrm{HPO}_{4}^{2-}+2 \mathrm{H}_{2} \mathrm{O} \\
\text { E de se esperar que em solos àcidos com ele- }
\end{array}
$$

vada concentração de hidrogênio esta reação seja intensa e o fósforo solüvel deste processo vă formar compostos de P-Al e P-Fe menos solúveis mas que podem solubilizar-se com a eleva ção do pH. KAMPRATH (1976) trabalhando com fösforo em cultura de milho obteve altas produções com $65 \mathrm{~kg} / \mathrm{ha}$ de $\mathrm{P}_{2} \mathrm{O}_{5}$ no solo que foi neutralizado $\circ \mathrm{Al}^{3+}$, e quando isto não ocorreu foi necessário $150 \mathrm{~kg} / \mathrm{ha}$ de $\mathrm{P}_{2}{ }_{5}$ para se obter a mesma produção.

Os estudos sobre fertilizantes fosfatados incluem a verificação do grau de eficiência de cada fosfato para as produções agrícolas. Uma das formas largamente empregadas é através do uso de solventes quimicos que determinam o grau de solubilidade. Alguns pesquisadores tais como AMES e KITSUTA (1931) chamam a atenção para o fato de que nem sempre as extra ções químicas dão Indicaçōes satisfatörias quanto ao teor de fósforo disponível às culturas. Assim sendo, a disponibilidade dos fosfatos é melhor compreendida sob o ponto de vista do grau de resposta das culturas e utilizaçao pelas plantas. Con- 
sideram ainda que o conhecimento da solubilidade do fósforo em certos fertilizantes, fornece apenas uma medida comparativa de sua provável disponibilidade e eficiência, mas decididamente solubilidade e disponibilidade não devem ser tomados como sinọ nimos. O trabalho destes autores realça a opinião de muitos pes quisadores de que o uso das plantas e suas capacidades de absorção fornecem informações mais satisfatörias. BRASIL SOBRINHO et alii (1965) estudaram a solubilidade em äcido cítrico a $2 \%$ do Termofosfato, Hiperfosfato, Fosfato da Flörida, Fosfato de Olinda, Fosfato Alvorada e Apatita do Araxä, e os resultados apontaram a maior solubilidade para o Termofosfato ao passo que os menos solúveis foram o Fosfato Alvorada e a Apatita do Araxá. Os mesmos autores partem da suposição de que os fosfatos mais solúveis em água, citrato de amônio e inclusive o ácido cítrico sejam os mais assimiláveis pelos vegetais.

Vários autores como BENNETT et alii (1957), AR MIGER et alii (1957) e FULEKY (1978) enfatizam uma sërie de fạ tores que interagem na disponibilidade de $P$ dos fosfatos de ro cha tais como: tipo de solo, calagem e, principalmente, a natu reza da fonte. BARTHOLOMEU (1937) estudou a disponibilidade de fosfatos de rocha em solos com diversos graus de acidez utilizando graminea como planta indicadora. Baseando-se nos resulta dos verificou que, de um modo geral, os solos ácidos näo aumentaram a absorção de $P$ pelas plantas, mas que o teor de fluor conforme a fonte interferiu nos resultados. 
Dentro da mesma I inha de pesquisa, VOLK(1943) estudou a influência do uso de calcārio e do sulfato de amônio nas culturas de linho e sorgo, constatou a ocorrência de melho res respostas do fosfato natural nos solos que não receberam calcärio. Quanto ao sulfato de amônio, provocou um abaixamento no pH acompanhado de um aumento na produtividade. Porēm, quando o calcário foi misturado com os fertilizantes, em doses necessárias, para a neutralizaçāo da acidez do adubo nitrogenado as diferenças não foram significativas em favor do $\left(\mathrm{NH}_{4}\right)_{2} \mathrm{SO}_{4}$.

ROSCOE et alii (1955) estudaram a influência do pH do meio de cultura da aveia na disponibilidade do fósfo ro do fosfato de rocha. 0 meio foi tratado com $\mathrm{Ca}(\mathrm{OH})_{2}$ de modo a obter uma variação de $\mathrm{pH}$ entre 4,9 e 7,4 , e as maiores prodú çōes com fosfato de rocha ocorreram ao pH 5,5. O mesmo trabaIho mostrou que quando o fosfato natural foi aplicado um mês antes da correção do pH a aveia cresceu melhor e absorveu mais fösforo que em situação invertida. Os resultados mostram, ainda, que o aumento progressivo do $\mathrm{pH}$ de 6,2 a 7,4 causaram decrëscimo nas produçōes, porém, a uma acidez acentuada de 4,9 houve drástico declínio na mesma. Extraçöes de fösforo foram feitas em ägua nos pHs 5,5 e 4,9 ; sendo que no primeiro extraiu $0,075 \mathrm{ppm} P$ e no segundo $0,22 \mathrm{ppm} P$ indicando maior solubiliza ção ao pH 4,9, mas por algum motivo näo foi prontamente absorvido pelas plantas. Uma das explicaçöes sugeridas pelos autores é a liberação de algum elemento do fertilizante em pH 4,9 e que estaria inibindo a absorção de pela aveia ou causando 
toxidez à cultura. Um destes elementos pode ser o fluor que ë muito ativo e mais intenso nos fosfatos de rocha, observam os pesquisadores.

objetivando medir o efeito do nitrogênio, enxôfre e calcário no uso de fosfato natural na cultura da alfafa, NICHOLS et alii (1960) constataram que nos dois solos estu dados $N$ e $S$ não afetaram de forma apreciável a absorção de fós foro, e que os aumentos de produção devido ao superfosfato e ao fosfato de rocha não diferiram significativamente em solos não calcariados. Porēm, onde houve calagem o superfosfato mostrou-se melhor que o fosfato natural.

Pesquisas conduzidas com fosfato solüvel e fosfatos de rocha (Moroco Rock e Carolina do Norte) por Juo e KANG (1979) em solos africanos, também demonstram a influência da acidez na solubilização dos fosfatos naturais. Os resulta dos obtidos nos solos não calcariados exibem melhor eficiência do fosfato de Rocha Carolina do Norte sobre o superfosfato tri plo, enquanto que sob o uso do corretivo da acidez inverteu-se a ordem de eficiência.

A inferioridade dos fosfatos naturais em relaçäo aos fosfatos solúveis na faixa de pHs mais adequados para as plantas em geral, empentiou muitos pesquisadores em estudos de acidificação de fosfatos. TERMAN et alii (1964) traba lharam nesse sentido e consideram os äcidos sulfúricos, fosföricos e nítricos os mais usados para a produção do superfosfa- 
to ou outros fosfatos solúveis em àgua ou citrato. Igualmente, como vários outros autores, compartilham na opinião de que a rocha é usualmente muito menos eficiente no crescimento das cul turas do que os fosfatos solüveis.

Tambēm o fenômeno da fixação do fösforo nos solos, induziu a experimentação a trabalhos com acidificação fracionária dos fosfatos e vārios estudiosos como Mclean e WHEELER (1964), LUTZ (1971) e novamente MCLEAN e WHEELER(1965) e LUTZ (1973) pesquisaram esta modalidade de acidificação obtendo resultados promissores com cerca de $20 \%$ de acidificação do fosfato de rocha.

\subsection{Extratores quimicos de fösforo}

Entre värios trabalhos que estudaram a disponibilidade do fósforo para os solos do Rio Grande do Sul encon tra-se o de ANGHINONI (1974) que investigou a recuperação de $P$ aplicado em niveis crescentes na forma de Ca $\left(\mathrm{H}_{2} \mathrm{PO}_{4}\right)_{2} \mathrm{H}_{2} \mathrm{O}$, ut lizando-se os métodos Carolina do Norte, Bray 2, 01 sen e Morgan. O método Carolina do Norte forneceu a melhor correlação entre o p extraído pela planta e o fósforo nativo, entretanto, Bray 2 e 01 sen apresentaram maior e menor capacidade de recupe raçäo, respectilvamente.

GOEPFERT (1976) avaliando a eficiência de adü bos fosfatados em solos äcldos, atravës do mëtodo de Mehlich, 
relata que os teores mais elevados de fósforo procedem de onde se usou fosfatos naturais podendo com isto subestimar a reco mendaçāo de adubo fosfatado.

Outras pesquisas conduzidas por FEITOSA e Van RAIJ (1976) em seis fontes de fösforo, com as culturas de trigo e milho e os extratores $\mathrm{H}_{2} \mathrm{SO}_{4} \mathrm{O}, 05 \mathrm{~N}$, Bray 2 e 01 sen tambēm obtiveram maiores teores do elemento no caso dos tratamentos com Apatita de Araxä e Hiperfosfato submetidos aos extratores ácidos. Sugerem os autores a dissolução daqueles fosfatos por estes extratores e observam ainda que com o tempo o Hiperfosfa to tendeu a se igualar aos fosfatos mais solüveis ao extrair se com H $\mathrm{SO}_{4} 0,05 \mathrm{~N}$ e Bray 2. Já o método de 01 sen acusou os menores teores, mas melhor correlacionou-se com a produção e absorção de P pelas plantas.

A eficiência do método de olsen aqui no Brasil tambēm foi relatada por PEREIRA e FARIA (1978), quando trạ balharam em um Vertissolo da Bahia com cultivo de milho. 0 método mostrou elevada eficiência na avaliação do p disponível para essa cultura neste tipo de solo.

o método Bray 1 de extração foi utilizado por CHIEN (1978) em um trabalho que visava avaliar o teor de fósfo ro de um solo ácido tratado com fosfato de rocha. No caso de fosfatos naturais com boa reatividade, 80 dias de incubação em sala comum foi suficiente para obter o máximo de reação e no caso de fosfatos menos reativos torna-se necessärio um periodo 
maior, pois seguramente uma parcela do fósforo extraído pelo mētodo é derivado de fosfato de rocha que ainda não reagiu.

os pesquisadores que têm experimentado extratores em solos que receberam fosfato natural têm chegado a um denominador comum nos seus resultados, FEITOSA (1978), SFREDO et alii (1979) são unânimes ao considerar os teores excessi vos de $P$ que os extratores àcidos indicam nos solos tratados com estes fosfatos e a falta de correspondência na produção.

NOVAIS E KAMPRATH (1979) trabalhando com os métodos Bray I, Carolina do Norte e Olsen, verificaram que as quantidades de $P$ extraídas de um solo mais argiloso pelo método Bray I foram bem menores que nos outros mais arenosos e atri buem a um consumo de àcido mais diluído que ë o Bray 1 pelo maior teor de argila. O trabalho desses autores elucida o comportamento distinto de um mesmo extrator quando se varia o tipor de solo.

outros pesquisadores tambēm têm obtido constạ taçöes de natureza similar como é o caso dos resultados conseguidos por FARIA e PEREIRA (1979) ao estudarem Bray 1 e Mehlich em Vertissol e Oxissol, pois no ültimo solo o método Bray l ex traiu mais $P$ do que Mehlich enquanto que no Vertissol a situação foi invertida.

Van RAIJ (1978) observa sobre uma possivel res trição ao uso de extratores äcidos no Brasil (com possível ex- 
ceção ao Bray l) devido principalmente ao fato de dissolverem a apatita dos fosfatos naturais e em solos äcidos adubados espera-se que o P-Lábil esteja em grande parte como P-Al, o que requer então outros métodos como Bray l, Resina e Olsen.

\subsection{Ebeito de fosfatos na cultura da soja}

A literatura sobre a fertilidade na cultura da soja faz uma sērie de alusões sobre os efeitos causados e a diferença de reação entre as variedades. INFORZATO e MASCARANHAS (1969) estudaram o sistema radicular da variedade Pelicano em Latossolo Roxo adubado e sem adubo e verificaram que com relaçäo ao total de raízes na presença e ausência de adubo não hou ve diferença, entretanto, o superfosfato simples utilizado acar retou um aumento de raízes finas a partir de certa profundidade. BRAGA (1970) descrevendo resultados experimentais com fosfato de Araxá e outras fontes considera que as leguminosas têm alto poder de aproveitamento de fösforo devendo, desta forma, apresentar melhores probabilidades de resposta aos fosfatos na turais do que as monocotiledôneas. Porēm, MASCARANHAS (1974) trabalhando em Latossolo Roxo do Estado de São Paulo, usou värias doses de $\mathrm{P}_{2}{ }^{0} 5$ no plantio da soja e não obteve resposta pạ ra o fertilizante fosfatado apesar dos baixos teores indicados pela anälise de solo. Interpretou como uma provável ineficiência do mëtodo de extração do P disponível à soja neste solo. 
foro como adubação corretiva no primeiro ano e de manutenção em cada semeadura de soja, em dois niveis de calcário no Rio Gran de do Sul, e concluiu que o corretivo da acidez aumentou o ren dimento de grãos de soja e a eficiência de todos os fosfatos in clusive os naturais, esta ültima conclusão é conträria aos resultados obtidos por ROSCOE et alii (1955) com a cultura da aveia. ABRÃo (1975) estudou o comportamento da soja diante da aplicação de Superfosfato Triplo, Hiperfosfato e Escória de Thomas em 0xissolo Santo Angelo (R.S.) e só obteve diferença significativa para as doses pois entre fontes não houve distin ção. Estes resultados são coerentes com as observações de BRAGA (1970) sobre a possibilidade de sucesso no uso de fosfatos naturais em leguminosas. Constatação desta natureza tambēm foi obtida por VIANNA et alii (1977) ao utilizarem a variedade Bragg nas seguintes fontes de fósforo: Superfosfato simples, Superfosfato Triplo, Hiperfosfato; Escória de Thomas e Termofosfato.

Alguns dos vários efeitos produzidos pelo fós foro na cultura da soja aparecem nas caracteristicas vegetais, como produção de grãos, alturas de planta e de inserção das primeiras vagens. MUZILLI e PALHANO (1976) trabalharam com curvas de resposta da cultura de soja à adubaçäo fosfatada e potässica em LRd no Paraná e a cada aumento na dose de ${ }^{\mathrm{P}_{2} \mathrm{O}_{5}}$ obtiveram determinados acréscimos na produtividade, alturas de planta e inserção das primeiras vagens. 
BRAGG et alii (1978) estudaram o efeito de uma série de fosfatos naturais no crescimento e produção de soja e os resultados deste experimento deixou bem caracteriza do a baixa reatividade das apatitas (Catalão, Patos de Minas e Araxā) enquanto que os fosfatos de aluminio (Fospal e Maranhão) e o Fosfato de Gafsa mostraram-se mais promissores, cabendo finalmente as melhores eficiencias ao Termofosfato magnesiano (Yoorin) e ao Superfosfato Triplo.

CORDEIRO et alii testaram o fosfato de Patos de Minas e o Fosfato de Gafsa em comparação ao Superfosfato Triplo aplicados na cultura da soja. A eficiencia destes fosfatos foi aferida com base na produção de grãos e seus valores para o Fosfato de Gafsa estão bem próximos do Superfosfa to Triplo enquanto que a apatita é menos eficiente das fontes.

\subsection{Diferenças entre variedades}

PAULA LIMA et alii (1974) conduziram experimentos com adubação fosfatada em variedades de soja e obtiveram respostas diferentes. A variedade UFV-1 foi mais produti va que Santa Rosa quando cultivada na ausencia de adubo, porēm com $200 \mathrm{~kg} / \mathrm{ha}$ de $\mathrm{P}_{2} \mathrm{O}_{5}$ as duas se igualaram. Resultados obt dos por MALAVOLTA et alii (1974) também ilustram esta diferença de comportamento entre as variedades, através de resultados experimentais que indicam melhores respostas da variedade Mineira que a pelicano devido a adubação com fósforo e potássio. 
Apesar da escassez de pesquisa sobre este assunto, aquelas em que foi possivel o acesso revelam a distinção de comportamento varietal ao se utilizar adubos fosfatados. CAMPELLO et alii (1974) comentam os seus resultados fazendo alug são è melhor resposta a fósforo da variedade Bragg que da Santa Rosa cultivadas em Oxissolo do Rio Grande do Sul. MOURA et alii (1974) com base nos seus resultados relatam que a varieda de Pérola semiprecoce, tendeu a responder aos niveis de adubação mais altos recomendados pelos laboratórios. 0 depoimentó destes autores aliado aos comentärios de CAMPELLO et alii (1974) e, mais tarde, aos de KOLLING et alii (1976) reforçam a opinião de que as variedades de ciclos mais curtos são mais exigentes em termos de fertilidade.

A grande maioria dos trabalhos usa com maior amplitude os pesos da produção vegetal para avaliar os resulta dos. Entretanto, BATAGLIA et alii (1977) promoveram uma competição mineral das sementes de nove cultivares de soja e, entre elas, destacou-se a cultivar Santa Rosa com baixo teor de fósforo e $1 A C-2$ em situação oposta com altos teores do elemento. 


\section{MATERIAL E METODOS}

\subsection{Seleção preliminar do solo}

Para o cumprimento dos objetivos deste trabaIho, procurou-se um solo capaz de oferecer respostas bem acentuadas da cultura da soja à adubação fosfatada e que originalmente apresentasse acidez mëdia.

E frequente os teores de fösforo nos solos in dicado pelo extrator químico não oferecerem fiel correlação com as respostas da cultura e devido a isso complementou-se a anälise de laboratörio com um teste preliminar em dois solos: Latossolo Vermelho Escuro orto Sërie Guamium (LVE) e Podzölico Vermelho Amarelo, variação Piracicaba, Sërie Godinhos (PVA), segundo RANZANI et alii (1966).

Os dois solos correspondem, respectivamente, ao Typic Haplorthox de acordo com LEPSCH e BUOL (1974) e Aquic Dystropets segundo DEMATTE et alii (1977). 
Os solos submeteram-se a presença e ausência de adubo fosfatado, plantando-se a variedade Bragg como indica dora. O solo da Série Godinhos revelou-se o mais indicado para strabalho.

\subsection{Coleta do solo, preparo e caracterização bísica} e quimica

Foi coletada a camada superficial do solo na p of undidade de $20 \mathrm{~cm}$ do perfil, sendo em seguida seca ao ar e submetida à peneira de $2 \mathrm{~mm}$.

A anālise física de caracterização do solo mostrou os seguintes teores: $15 \%$ de areia, $55 \%$ de 1 imo e $30 \%$ de argila.

A anälise quimica forneceu os seguintes resul tados expressos em e.mg/100 g TFSA:

$$
\begin{aligned}
\mathrm{Ca}^{2+}=3,00 & \mathrm{Al}^{3+}=1,7 \\
\mathrm{Mg}^{2+}=0,91 & \mathrm{H}^{+}+\mathrm{Al}^{3+}=6,5 \\
\mathrm{~K}^{+}=0,30 &
\end{aligned}
$$

e os demais resultados assim se apresentaram:

$$
\begin{aligned}
& \qquad \mathrm{pH} \text { em ägua }=5,1 ; C \%=0,9 \text { e } P(p p m)=6,7 . \\
& \text { Todas as determinaçōes foram feitas seguindo } \\
& \text { a metodologia proposta por CATANI e JACINTHO (1974). }
\end{aligned}
$$




\subsection{Esquema de tratamentos e delineamento experimental}

Foi estudado o comportamento de três varieda des de soja: Bragg $\left(V_{1}\right)$, Paraná $\left(V_{2}\right)$ e Santa Rosa $\left(V_{3}\right)$ quando adubadas com fosfato solúvel (fosfato monocálcico), fosfato natural (fosfato Alvorada) e sem fertilizante fosfatado.

Os tratamentos de solo estão assim representa dos:

$T_{1}=$ Fosfato Monocälcico em incubação após a calagem $T_{2}=$ Fosfato Alvorada em incubação apös a calagem

$T_{3}=$ Sem fosfato apös a calagem

$T_{4}=$ Fosfato Monocálcico em incubação anterior a calagem $T_{5}$ = Fosfato Alvorada em incubação anterior a calagem $T_{6}=$ Sem fosfato anterior a calagem.

Os fosfatos ficaram 240 dias incubando e o $\mathrm{Ca}(\mathrm{OH})_{2}$ empregado como corretivo da acidez permaneceu 15 dias em incubação.

o delineamento experimental constitui um ensaio fatorial de $6 \times 3$, inteiramente ao acaso com quatro repetiçöes. 


$$
\text { Quadro da Anälise }
$$

\begin{tabular}{lc}
\hline Causa da variação & $G L$ \\
\hline Tratamentos $(T)$ & 5 \\
Variedades $(V)$ & 2 \\
Int. T V & 10 \\
\hline Parcelas & $(17)$ \\
Residuo & 54 \\
\hline Total & 71 \\
\hline
\end{tabular}

\subsection{Determinaçāo da quantidade de $\mathrm{Ca}(\mathrm{OH})_{2}$ e aplicação.}

A determinação da quantidade de hidröxido de cälcio para elevar o $\mathrm{pH}$ atë 6,5 foi feita através da incubação do solo com doses crescentes de $\mathrm{Ca}(\mathrm{OH})_{2}$.

Foi uniformemente aplicado $9,27 \mathrm{~g}$ de $\mathrm{Ca}(\mathrm{OH})_{2}$ no solo de cada vaso e, em seguida, irrigou-se com ägua distilada atē $60 \%$ da capacidade māxima de retenção de āgua. Logo apös o período de incubação do solo com o corretivo foi atingido $\mathrm{o}$ pH 6,6 .

$$
\text { Cada vaso recebeu } 4,6 \mathrm{~kg} \text { de TFSA. }
$$




\subsection{Preparo e aplicação dos fosfatos}

Como fontes de fösforo foram utilizados os se guintes fosfatos:

\begin{tabular}{|c|c|c|c|c|}
\hline $\begin{array}{l}\text { Fontes de } \\
\text { fösforo } \\
\text { empregadas }\end{array}$ & $\begin{array}{c}\text { P solūvel } \\
\text { em } \\
\text { àgua }\end{array}$ & $\begin{array}{l}\text { P solüvel } \\
\text { em ác.citrico } \\
2 \% \quad 1: 1000\end{array}$ & $P$ & total \\
\hline Fosfato monocälcico & $40 \%$ & $42 \%$ & & $45 \%$ \\
\hline Fosfato Alvorada & $0 \%$ & $5 \%$ & & $27 \%$ \\
\hline
\end{tabular}

Os fosfatos passaram totalmente em peneira de "200 mesh", e os tratamentos que receberam fósforo de uma ou de outra fonte foram dosados com $100 \mathrm{ppm}$ de P baseando - se em seus respectivos teores de fósforo total. Este valor corres ponde às seguintes quantidades dos fosfatos por vaso: $1,87 \mathrm{~g}$ de $\mathrm{Ca}\left(\mathrm{H}_{2} \mathrm{PO}_{4}\right)_{2} \mathrm{H}_{2} \mathrm{O}$ e $3,91 \mathrm{~g}$ de fosfato Alvorada.

\subsection{Local e inicio de execução}

o experimento iniciou-se em 1977 e foi conduzido em casa de vegetação, na Escola Superior de Agricultura "Luiz de Queiroz". O solo utilizado foi condicionado em vasos de barro, pintados internamente com "Neutrol" e com capacidade para receber $5 \mathrm{~kg}$ de Terra Fina seca ao Ar (TFSA). 


\subsection{Experimento em casa de vegetação}

As sementes de soja procederam do Centrao $\mathrm{Na-}$ cional de Pesquisa de Soja, e foram para o germinador de areia em 15/08/79 para serem transplantadas seis plântulas por vaso, nümero este que permaneceu durante uma semana quando então de $\underline{s}$ bastou-se reduzindo para quatro plantas por vaso.

Diariamente foi controlada a umidade conforme a demanda de àgua, e o periodo de luz natural foi complementado por mais quatro horas de iluminação com lâmpadas incandes centes, para controle do fotoperíodo devido a semeadura fora de època.

Aos vinte e cinco dias apös a emergência,o so lo recebeu um equivalente a $20 \mathrm{ppm}$ de $N$ atravës da ägua de irrigação e, em seguida, foi usada a seguinte adubação foliar:

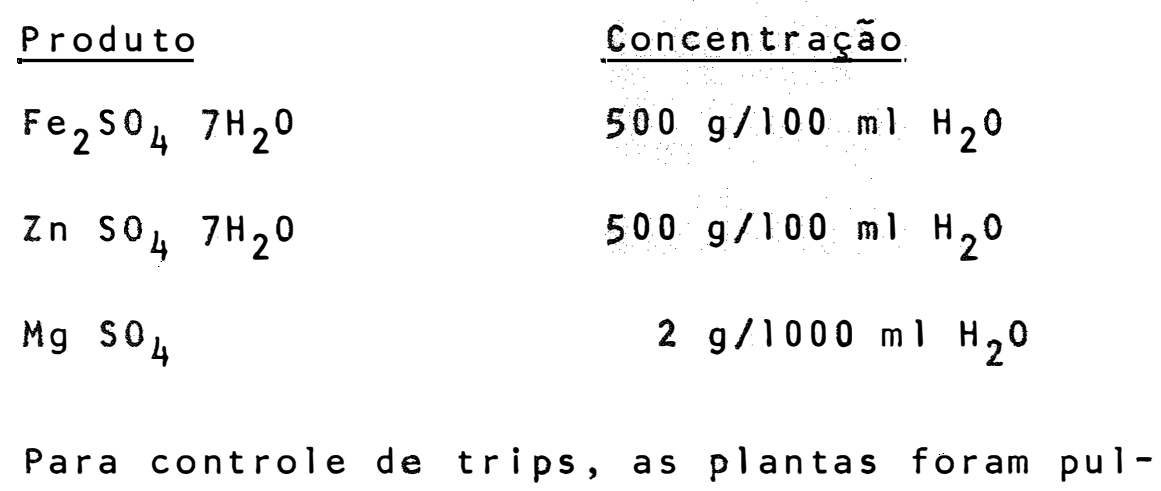
verizadas com Decamethrin na concentração de $25 \%$.

Sessenta e dois días após a emergência, as plantas foram fotografadas, tomou-se a medida de suas alturas 
(cm) acompanhando a contagem do nümero de internödios. Na mesma ocasião as plantas foram cortadas a $2 \mathrm{~cm}$ da superfície do solo, fazendo-se coleta de folhas e caules separadamente.0 si tema radicular tambēm foi aproveitado para obtenção do seu peso seco.

Todo o material colhido foi imediatamente seco em estufa a temperatura de $70^{\circ} \mathrm{C}$, para posterior registro dns pesos e moagem.

\subsection{Amostragens e anälises do fósforo do solo}

Aos 30 e 240 dias de incubação com fosfatos, todos os tratamentos foram amostrados para as anälises de fösforo.

As extrações deste elemento foram feitas empregando-se os seguintes métodos:

a) Mëtodo de Mehlich (NELSON et alii, 1954), que serä designado por "Ej"., neste trabalho.

b) Mētodo Bray 2 (BRAY e KURTZ, 1945) - "E2"!

c) Método de olsen (OLSEN et alii, 1954) com ligeira modificação, não se utilizando car vão ativado e introduzindo o uso de super floco 127 na concentração de $0,5 \mathrm{~g} / 10$ lt"E $\mathrm{E}_{3}$ ". 


\subsection{Anälises quimicas de tecido}

As determinaçōes de $P$ e outros elementos do tecido foliar foram feitas seguindo-se a metodologia adotada pelo Instituto Agronōmico do Paranä.

4.10. Anälises estatisticas

Foram feitas anälises de variância com desdobramento do nümero de grau de liberdades, utilizou-se o teste de Tukey $5 \%$ e foi tambēm usado teste de correlação linear. 


\section{RESULTADOS E DISCUSSAO}

\subsection{Avaliaçöes biolögicas}

5.1.1. Avaliação dos tratamentos de solo sobre algu mas caracteristicas vegetais

Os tratamentos de solo empregados mostraram di. ferenças significativas entre si dentro de cada uma das variedades estudadas em todas as características contidas na Tabe$1=1$.

\subsubsection{Altura das plantas}

o contraste das médias gerais do efeito dos tratamentos na altura das plantas, Tabela 3; evidencia diferen ças significativas entre o fosfato solüvel, fosfato natural e testemunha independentemente da ordem de correção da acidez, porëm, näo houve influência da ordem de correção da acidez no efeito dos fosfatos. 
As comparações entre tratamentos dentro de cada uma das variedades estudadas são semelhantes à apresentação anterior e em quase todos os casos o fosfato monocálcico superou o Fosfato Alvorada que, por sua vez, foi superior a testemunha. Trabalhos com niveis crescentes de fosfato solúvel em LRd no Paranā conduzidos por MUZILLI e PALHANO (1976) realçam o efeito do fösforo na altura das plantas de soja, cultiva das em condições de resposta ao elemento. A Figura 1 mostra o efeito das fontes de $P$ na altura das plantas.

\subsubsection{Nümero de internödios}

Esta característica vegetal também foi influen ciada pelas fontes de fósforo empregadas sendo que também a ordem de influência tanto para as médias gerais independente de variedade como dentro de cada uma delas ficou assim situada: Fosfato Monocälcico, F. Alvorada e Testemunha. Estas considelaçōes foram extraídas da Tabela 4 a qual permite também obser var a não influência das duas condições de aplicação do $\mathrm{Ca}(\mathrm{OH})_{2}$.

\subsubsection{Peso de folhas}

Os dados da Tabela 5 colocam o fosfato solüvel em condição de superioridade aos demais tratamentos, comprovando os resultados de CORDEIRO et alii (1979) que obtiveram uma eficiência relativa do Superfosfato Triplo superior aos fosfatos naturais empregados. O Fosfato Alvorada foi estatisticamente superior à testemunha com exceção dos dois ülti- 
mos tratamentos dentro das variedades Bragg e Santa Rosa.

Uma anälise comparativa entre a ordem de apli caçäo do corretivo da acidez, por exemplo, T1, T2 e T3 com T4, T5 e T6, respectivamente, demonstra diferenças entre os trată mentos que receberam fosfato, favorecendo aqueles que foram aplicados em condição de solo com pH pröximo de 6,5.

\subsubsection{Peso de caules}

Esta característica tambèm foi estudada e a comparação entre as mëdias se encontra na Tabela 6 . I gualmente como nas caracteristicas anteriores o fosfato monocálcico produziu efeitos superiores ao fosfato natural e este tambēm foi melhor que a testemunha com exceção dos ültimos dois tratamentos dentro das variedades Bragg e Santa Rosa.

As respectivas comparaçöes de $\mathrm{T}_{1}, \mathrm{~T}_{2}$ e $\mathrm{T}_{3}$ com T4. T5 e T6 confrontam a ordem de aplicação do corretivo da acidez, com resultados favoráveis às fosfatagens em condiçōes de solo com pH pröximo de 6,5.

\subsubsection{Peso de raizes}

Os resultados da Tabela 7 e a Figura 2 reve lam a sensibilidade do sistema radicular às fontes de fósforo.

o fosfato solüvel proporcionou o maior peso de raizes seguido pelo fosfato natural e por ültimo a testemunha. O Fosfato Alvorada somente Igualou-se a testemunha quando 
foi aplicado em condiçōes de solo com pH pröximo de 5,0 dentro das variedades Bragg e Santa Rosa. A confrontação da ordem de aplicação do corretivo demonstra diferenças estatísticas sign i ficativas, com exceção do fosfato natural ( $T_{2}$ e T5) na variedade Paraná e das testemunhas ( $T_{3}$ e T6) na variedade Santa Rosa

o sistema radicular da cultura da soja jä tem sido objeto de estudo por värios pesquisadores. INFORZATO e MASCARANHAS (1964) estudaram o sistema radicular desta cultura em Latossolo Roxo na presença e auséncia de fösforo e embora nào tenham constatado diferenças significativas de peso, verificaram um aumento de raízes finas onde se processou a aduba çào.

Todas as características abordadas até o momento como: altura de plantas, nümero de internódios, peso de folhas, peso de caules e peso de raizes atingiram seus maiores vilores sob o efeito do fosfato monocálcico de que sob a infiuéncia do fosfato natural, isto se deve à menor solubilidade do ültimo em relação ao primeiro. BRASIL SOBRINHO et alii(1965) estudando a solubilidade de diversos fosfatos em ácido cítrico a $2 \%$, constataram que o Fosfato Alvorada e a Apatita de Araxä for am os adubos menos solúveis, com curvas de solubilidade mul tu semelhantes. Realçam ainda os mesmos autores a concepção ge ral de que os adubos mais solüveis em água, citrato de amónio e mesmo àcido cítrico são os mais assimiläveis pelos vegetais. 
A diferença encontrada no confronto das ordens de aplicação do corretivo da acidez nos peso de folhas, peso de caules e peso de raízes, näo permite atribuir-se aos efeitos de maior ou menor solubilização do fosfato natural,pois os dados das Tabelas 2 e 4 no Apêndice revelam uma interferência do Mn nos tratamentos $\mathrm{T}_{4}$, $\mathrm{T}_{5}$ e $\mathrm{T}_{6} 6$, tendo em vista seus ele vados teores quando comparados com os da Tabela 5 no Apêndice, proposta por JONES (1966 e 1968).

\subsubsection{Comportamento, entre variedades, algumas caracteristicas vegetais}

As variedades usadas neste experimento submeteram-se a análise de variancia especificada na Tabela 2. Pode se verificar que as características vegetais contidas na Tabela apresentaram värios casos de diferenças não significativas entre variedades.

$$
\begin{aligned}
& \text { 5.1.2.1. Alturas de plantas } \\
& \text { o contraste entre as medias das variedades }
\end{aligned}
$$

dentro de tratamentos. Tabela 3 e Figura 3 , acusam uma superio ridade da Bragg sobre as demais, exceptuando-se em $T_{5}$ onde não diferiu e em T6 quando apenas superou a variedade Santa Rosa, embora a tendencia nestes dois ültimos tratamentos seja seme Ihante aos anteriores. A similaridade do comportamento das variedades dentro de tratamentos exclui a Influencia de cada uma das fontes de fösforo no resultado da competiçāo entre elas. 


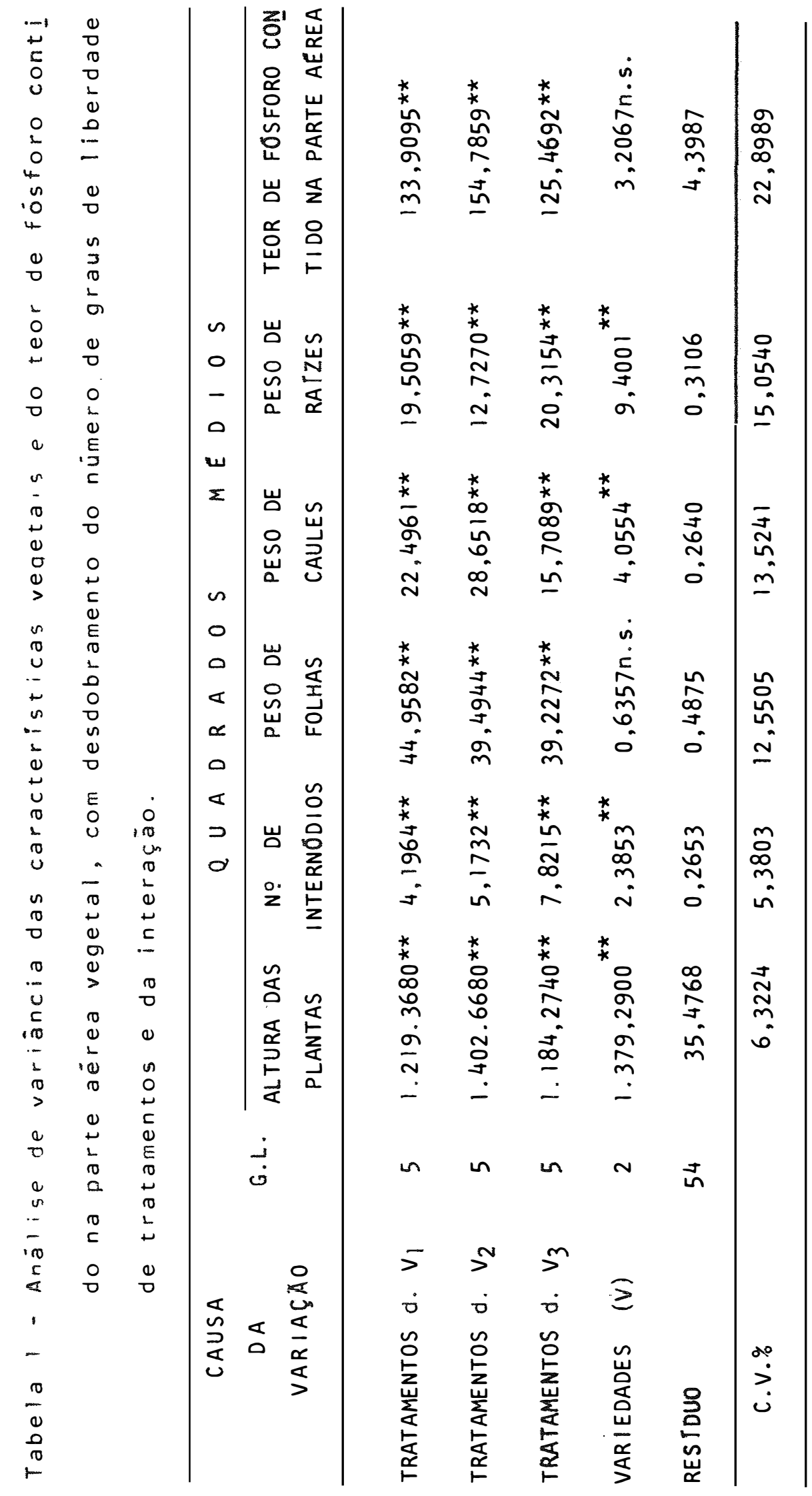




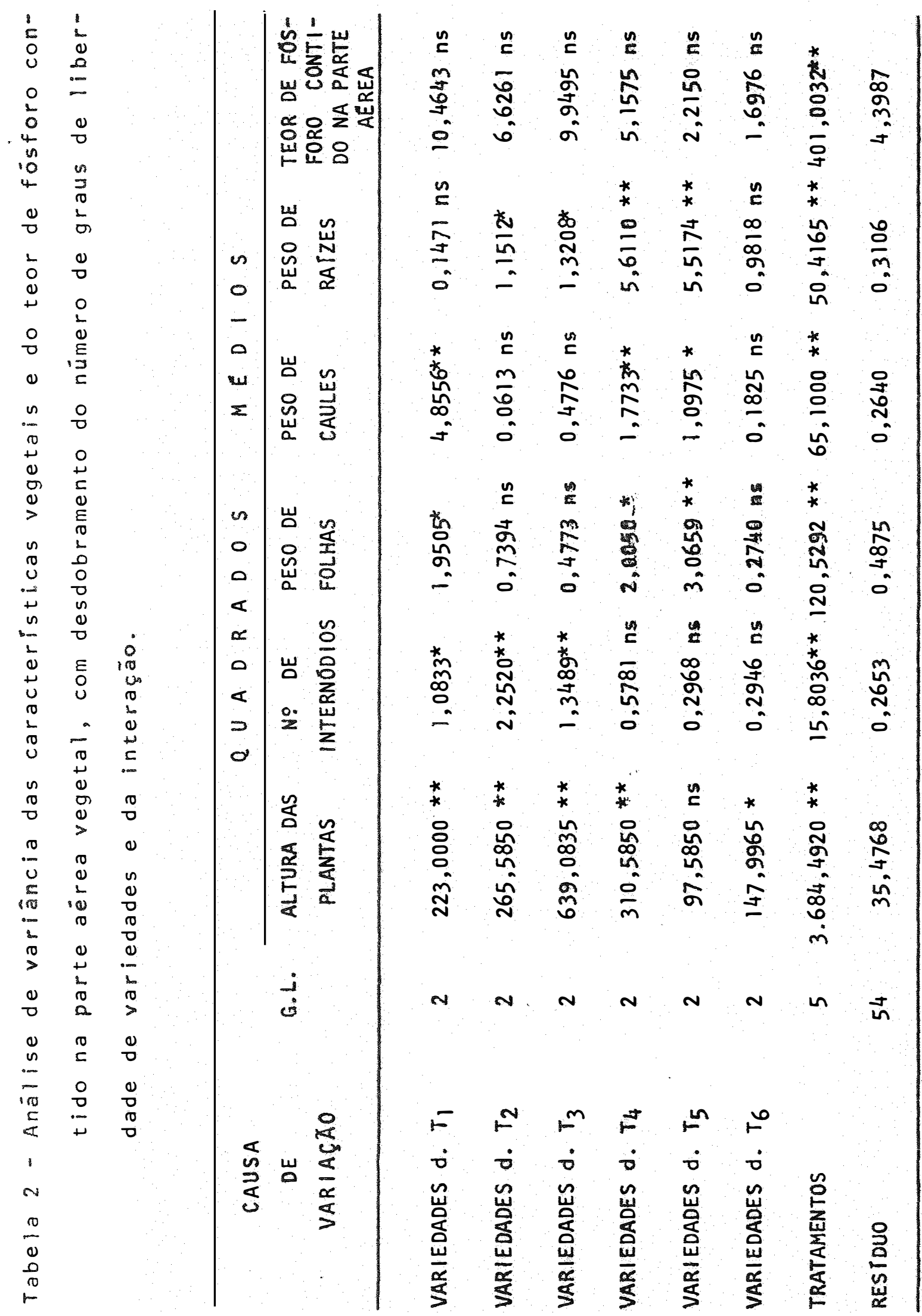


Tabela 3 - Altura das plantas $(\mathrm{cm})$ aos 62 dias após emergência. Médias de quatro repetições e médias gerais de tratamentos e variedades

\begin{tabular}{|c|c|c|c|c|}
\hline \multirow{2}{*}{ TRATAMENTOS } & \multicolumn{3}{|c|}{ VAR IEDADES } & \multirow{2}{*}{$\begin{array}{l}\text { MED IAS } \\
\text { GERA IS DE } \\
\text { TRATAMENTO }\end{array}$} \\
\hline & BRAGG & PARANA & S. ROSA & \\
\hline $\mathrm{Ca}(\mathrm{OH})_{2}+\mathrm{F}$. monocālcico $\left(\mathrm{T}_{1}\right)$ & 126,25 & 114,75 & 112,25 & 117,75 \\
\hline $\mathrm{Ca}(\mathrm{OH})_{2}+\mathrm{F}$. Alvorada & 101,75 & 86,00 & 90,25 & 92,67 \\
\hline $\mathrm{Ca}(\mathrm{OH})_{2}$ sem fosfato & 91,00 & 66,00 & 75,25 & 77,42 \\
\hline $\mathrm{F}$. monocālcico $+\mathrm{Ca}(\mathrm{OH})_{2}\left(\mathrm{~T}_{4}\right)$ & 120,75 & 103,00 & 109,00 & 111,92 \\
\hline $\mathrm{F}$. Alvorada $+\mathrm{Ca}(\mathrm{OH})_{2}$ & 96,75 & 93,25 & 87,00 & 92,33 \\
\hline Sem fosfato com $\mathrm{Ca}(\mathrm{OH})_{2} \quad\left(\mathrm{~T}_{6}\right)$ & 81,00 & 71,00 & 70,00 & 74,00 \\
\hline MEDIAS GERAIS DE VARIEDADES & 102,92 & 89,00 & 90,62 & \\
\hline
\end{tabular}

Tukey $5 \%$

D.M.S. para tratamentos dentro de variedades: 12,45

D.M.S. para variedades dentro de tratamentos: 10,16

D.M.S. para tratamentos (Geral) : 7,19

D.M.S. para variedades (Geral) : 4,15 
Tabela 4 - Nümero de internōdios aos 62 dias apōs a emergência Médias de quatro repetições e mëdias gerais de tratamentos e variedades.

\begin{tabular}{|c|c|c|c|c|c|}
\hline \multirow{2}{*}{ TRATAMENTOS } & & \multicolumn{3}{|c|}{ VARIEDADES } & \multirow{2}{*}{$\begin{array}{l}\text { MEDIAS } \\
\text { GERAIS DE } \\
\text { TRATAMENTOS }\end{array}$} \\
\hline & & BRAGG & PARANA & S. ROSA & \\
\hline $\mathrm{Ca}(\mathrm{OH})_{2}+\mathrm{F}$. monocälcico & $\left(T_{1}\right)$ & 9,69 & 8,94 & 9,94 & 9,52 \\
\hline $\mathrm{Ca}(\mathrm{OH})_{2}+\mathrm{F}$. Alvorada & $\left(T_{2}\right)$ & 8,44 & 7,69 & 9,19 & 8,44 \\
\hline $\mathrm{Ca}(\mathrm{OH})_{2}$ sem fosfato & $\left(T_{3}\right)$ & 7,25 & 6,31 & 7,37 & 6,98 \\
\hline F. monocálcico $+\mathrm{Ca}(\mathrm{OH})_{2}$ & $\left(T_{4}\right)$ & 8,75 & 8,81 & 9,44 & 9,00 \\
\hline F. Alvorada $+\mathrm{Ca}(\mathrm{OH})_{2}$ & $\left(T_{5}\right)$ & 8,06 & 8,12 & 7,62 & 7,93 \\
\hline Sem fosfato $\operatorname{com~} \mathrm{Ca}(\mathrm{OH})_{2}$ & $\left(T_{6}\right)$ & 6,87 & 6,44 & 6,37 & 6,56 \\
\hline MEDIAS GERAIS DE VARIEDAL & & 8,18 & 7,72 & 8,32 & \\
\hline
\end{tabular}

Tukey $5 \%$

D.M.S. para tratamentos dentro de variedades: 1,08

D.M.S. para variedades dentro de tratamentos: 0,88

D.M.S. para tratamentos (Geral) $: 0,62$

D.M.S. para variedades (Geral) : 0,36 
Tabela 5 - Peso de folhas (g/vaso). Mëdias de quatro repetições e médias gerais de tratamentos e variedades.

\begin{tabular}{|c|c|c|c|c|}
\hline \multirow{2}{*}{ TRATAMENTOS } & \multicolumn{3}{|c|}{ VARIEDADES } & \multirow{2}{*}{$\begin{array}{l}\text { MEDIAS } \\
\text { - GERAIS DE } \\
\text { TRATAMENTOS }\end{array}$} \\
\hline & BRAGG & PARANA & S. ROSA & \\
\hline $\mathrm{Ca}(\mathrm{OH})_{2}+\mathrm{F}$. monocálcico $\left(\mathrm{T}_{l}\right)$ & 11,47 & 10,31 & 10,23 & 10,67 \\
\hline $\mathrm{Ca}(\mathrm{OH})_{2}+\mathrm{F}$. Alvorada $\quad\left(\mathrm{T}_{2}\right)$ & 5,45 & 5,30 & 6,11 & 5,62 \\
\hline $\mathrm{Ca}(\mathrm{OH})_{2}$ sem fosfato & 3,38 & 2,76 & 3,32 & 3,15 \\
\hline F. monocälcico $+\mathrm{Ca}(\mathrm{OH})_{2}\left(\mathrm{~T}_{4}\right)$ & 7,17 & 8,52 & 7,47 & 7,72 \\
\hline F. Alvorada $+\mathrm{Ca}(\mathrm{OH})_{2} \quad\left(\mathrm{~T}_{5}\right)$ & 3,75 & 4,99 & 3,29 & 4,01 \\
\hline Sem fosfato com $\mathrm{Ca}(\mathrm{OH})_{2} \quad\left(\mathrm{~T}_{6}\right)$ & 2,30 & 2,40 & 1.91 & 2,20 \\
\hline MEDIAS GERAIS DE VARIEDADES & 5,59 & 5,71 & 5,39 & \\
\hline
\end{tabular}

Tukey $5 \%$

D.M.S. para tratamentos dentro de variedades: 1,46

D.M.S. para variedades dentro de tratamentos: 1,19

D.M.S. para tratamentos (Geral) : 0,84

D.M.S. para variedades (Geral) : 0,49 
Tabela 6 - Peso de caules (g/vaso). Médias de quatro repetições e médias gerais de tratamentos e variedades.

\begin{tabular}{|c|c|c|c|c|}
\hline \multirow[t]{2}{*}{ TRATAMENTOS } & \multicolumn{3}{|c|}{ VAR I EDADES } & \multirow{2}{*}{$\begin{array}{c}\text { MEDIAS } \\
\text { - GERAIS DE } \\
\text { TRATAMENTOS }\end{array}$} \\
\hline & BRAGG & PARANA & S. ROSA & \\
\hline $\mathrm{Ca}(\mathrm{OH})_{2}+\mathrm{F}$. monocālcico $\left(\mathrm{T}_{1}\right)$ & 8,19 & 8,70 & 6,59 & 7,83 \\
\hline $\mathrm{Ca}(\mathrm{OH})_{2}+\mathrm{F}$. Alvorada & 3,54 & 3,71 & 3,79 & 3,68 \\
\hline $\mathrm{Ca}(\mathrm{OH})_{2}$ sem fosfato & 2,43 & 1,86 & 1,82 & 2,04 \\
\hline F. monocālcico $+\mathrm{Ca}(\mathrm{OH})_{2}\left(\mathrm{~T}_{4}\right)$ & 4,98 & 5,70 & 4,37 & 5,02 \\
\hline F. Alvorada $+\mathrm{Ca}(\mathrm{OH})_{2}$ & 2,65 & 3,19 & 2,14 & 2,66 \\
\hline Sem fosfato com $\mathrm{Ca}$ & 1,74 & 1,63 & 1,33 & 1,57 \\
\hline MEDIAS GERAIS DE VARIEDADES & 3,92 & 4,13 & 3,34 & \\
\hline
\end{tabular}

Tukey $5 \%$

D.M.S. para tratamentos dentro de variedades: 1,07

D.M.S. para variedades dentro de tratamentos: 0,88

D.M.S. para tratamentos (Geral) : 0,62

D.M.S. paravariedades (Geral) : 0,36 
Tabela 7 - Peso de raízes (g/vaso). Médias de quatro repetições e médias gerais de tratamentos e variedades.

\begin{tabular}{|c|c|c|c|c|}
\hline \multirow{2}{*}{ TRATAMENTOS } & \multicolumn{3}{|c|}{ VARIEDADES } & \multirow{2}{*}{$\begin{array}{c}\text { MEDIAS } \\
\text { GERAIS DE } \\
\text { TRATAMENTOS }\end{array}$} \\
\hline & BRAGG & PARANA & S. ROSA & \\
\hline $\mathrm{Ca}(\mathrm{OH})_{2}+\mathrm{F}$. monocälcico $\left(\mathrm{T}_{1}\right)$ & 7,24 & 7,11 & 7,49 & 7,28 \\
\hline $\mathrm{Ca}(\mathrm{OH})_{2}+\mathrm{F}-\mathrm{Alvorada}$ & 3,71 & 4,77 & 4,33 & 4,27 \\
\hline $\mathrm{Ca}(\mathrm{OH})_{2}$ sem fosfato & 2,39 & 3,29 & 2,22 & 2,63 \\
\hline F. monocälcico $+\mathrm{Ca}(\mathrm{OH})_{2}\left(\mathrm{~T}_{4}\right)$ & 3,32 & 5,47 & 3,54 & 4,11 \\
\hline F. Alvor ada $+\mathrm{Ca}(\mathrm{OH})_{2}$ & 1,61 & 3,79 & 1,94 & 2,45 \\
\hline Sem fosfato com $\mathrm{Ca}(\mathrm{OH})_{2} \quad\left(\mathrm{~T}_{5}\right)$ & 1,06 & 2,02 & 1,33 & 1,47 \\
\hline MEDIAS GERAIS DE VARIEDADES & 3,22 & 4,41 & 3,47 & \\
\hline
\end{tabular}

Tukey $5 \%$

D.M.S. para tratamentos dentro de variedades: 1,16 D.M.S. para variedades dentro de tratamentos: 0,95 D.M.S. para tratamentos (Geral) $: 0,67$ D.M.S. para variedades (Geral) : 0,39 


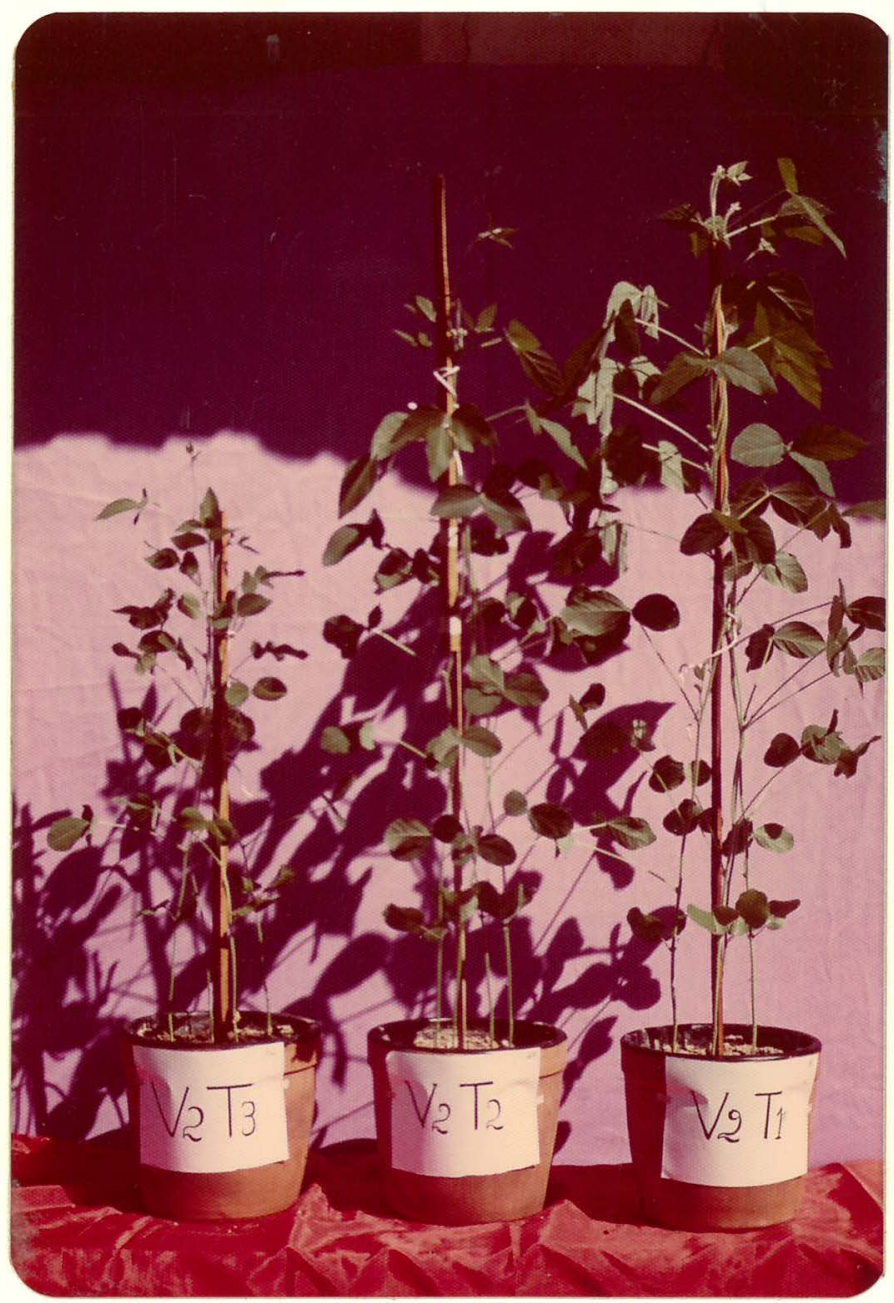

Fig. I - Desenvolvimento vegetativo da varie dade Paranā $\left(V_{2}\right)$ na testemunha $\left(T_{3}\right)$ e na presença de fosfato Alvorada $\left(T_{2}\right)$ e fosfato solüvel $\left(T_{1}\right)$. 


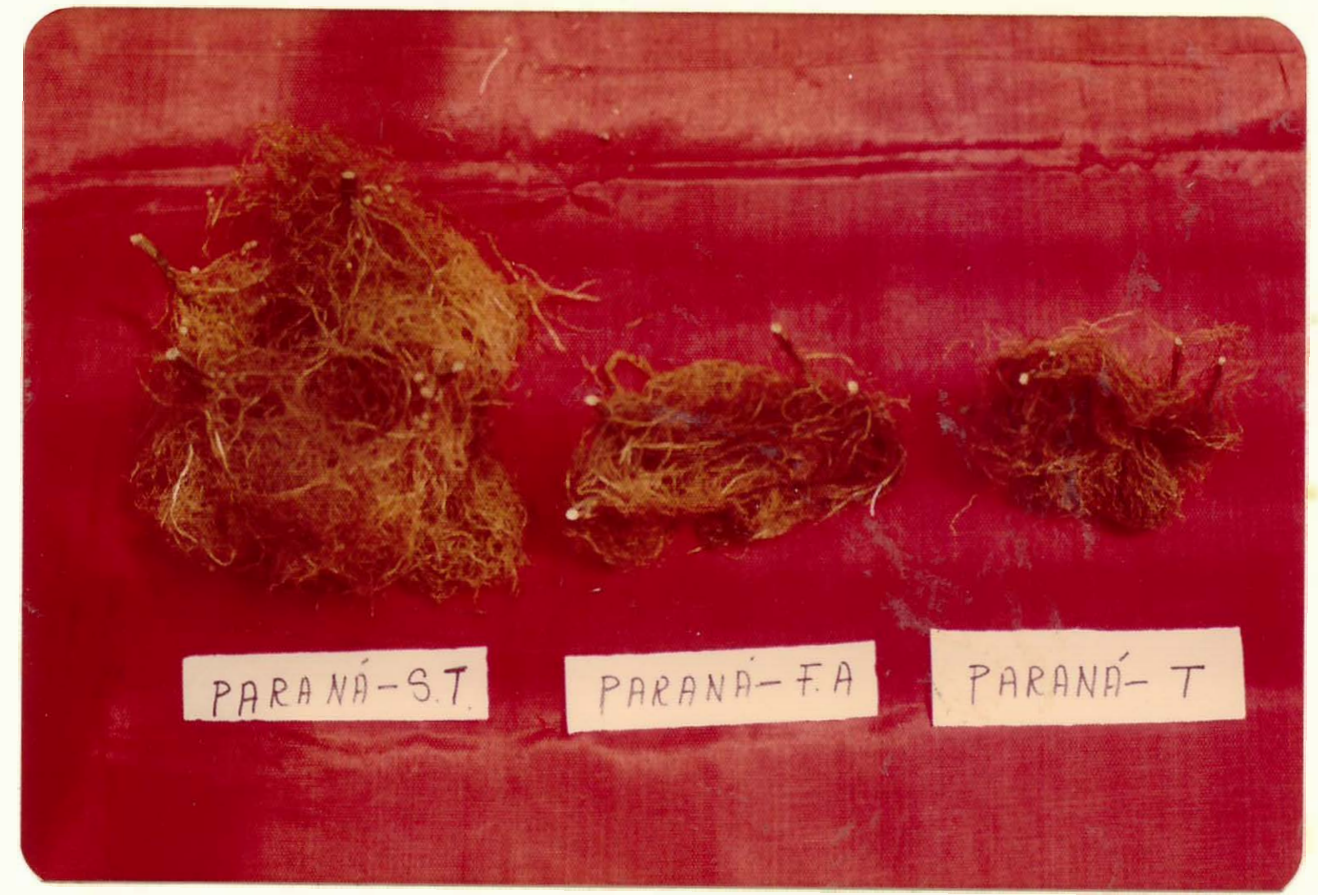

Fig. 2 - Desenvolvimento do sistema radicular da variedade Paranä na presença de fosfato solūvel (S.T.), fos fato Alvorada (F.A.) e na testemunha (T). 


\subsubsection{Nümero de internödios}

Ao examinar-se as médias varletais da Tabela 4 em $T_{1}, T_{2}$ e $T_{3}$ é visível o menor nümero de internödios da varie dade Paraná em relação as outras que não diferem entre sí. No caso em que os fosfatos foram aplicados em solo ácido as variedades não diferiram entre si dentro de cada tratamento, possi velmente seja devido tambēm ao Manganês, pois a desvantagem anterior da variedade Paraná foi diminuida pelo fato de absorver menos manganês que Bragg e Santa Rosa, como pode ser comprovado Nas Tabelas 2 e 4 do Apēndice.

BROWN e JONES (1977) ao estudarem a tolerância de algumas variedades de soja a Fe e Mn verificaram que as variedades Bragg e Forrest apresentaram sintomas mais severos de toxidez de manganès do queas outras testadas.

\subsubsection{Peso de folhas}

A anälise comparativa entre as variedades dentro dos tratamentos na Tabela 5 indica diferenças significativas apenas nos tratamentos $T_{1}, T_{4}$ e $T_{5}$ e em cada tratamento a variedade Paranā quando não superou as demais apenas equiparou se a elas estatisticamente.

\subsubsection{Peso de caules}

As variedades Bragg e Paraná comportaram-se de forma igual em cada um dos tratamentos sendo que Santa Rosa 
foi inferior a elas apenas no tratamento $T_{1}$ pois em $T_{4}$ e $T_{5}$ apenas foi superadapela variedade Paraná e nos demais tratamentos não houve diferenças significativas entre as variedades, Tabela 6 .

Uma anälise conjunta dos pesos de folhas e de caules das três variedades dentro do fosfato solúvel ( $T_{1}$ ) mos tra que as variedades Bragg e Paraná superam Santa Rosa, o que é concordante com os resultados de KOLLING et alii (1976) ao testar algumas variedades entre as quais a Bragg constatou que esta juntamente com o Planalto apresentaram maior capacidade de resposta a altos niveis de fertilidade. A variedade Bragg não comportou-se de idêntica forma no fosfato solúvel do trata mento $T_{4}$ possivelmente devido a interferência do manganês e a sua maior capacidade de absorvê-lo do que as variedades paraná e Santa Rosa.

A inexistência de diferenças significativas, tanto para folhas como para caules dentro do fosfato Alvorada no tratamento $T_{2}$ pode ser melhor llustrado através da figur 3 apesar da diferença de altura.

Por outro lado, as diferenças existentes entre variedades, para folhas e caules, dentro do fosfato Alvor da no tratamento $T_{5}$ não permite avaliação tendo em vista a interferència do Mn. 


\subsubsection{Peso de raizes}

Quanto a esta característica vegetal observa-se na Tabela 7 , que em nenhum dos tratamentos de solo a variedade Paranä ficou em condiçöes de inferioridade às demais variedades e que em todos os tratamentos Bragg e Santa Rosa não diferiram entre si.

\subsection{Avaliaçöes quimicas.}

5.2.1. Avaliação dos tratamentos de solo sobre os teores de fósboro

A anälise de variância do teor de fösforo con tido na parte aérea, Tabela 1 , indica a existência de diferenças significativas entre os tratamentos dentro de cada varieda de, entretanto o Teste de $F$ não acusou diferenças significativas entre as variedades.

o mesmo tipo de anālise para o fösforo no solo aos 30 e aos 240 dias de incubação, Tabela 8, mostrou diferenças significativas entre os tratamentos dentro dos extratores e também entre os extratores.

5.2.1.1. Teor de fósforo contido na parte aêrea vegetal

As mëdias da Tabela 10 mostram que em todas as circunstâncias o fosfato monocálclco sobrepujou o fosfato 


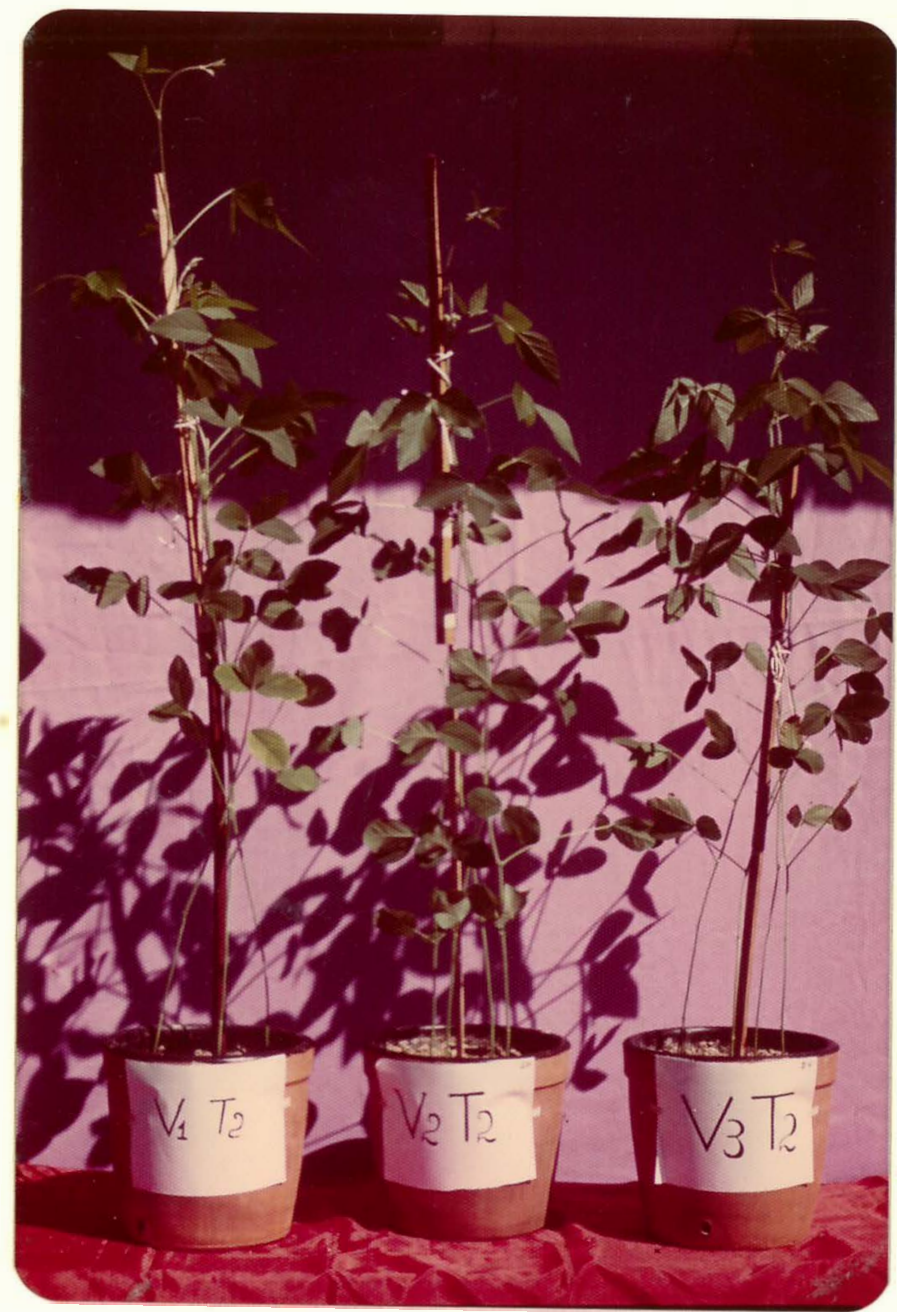

Fig. 3 - Desenvolvimento vegetativo das variedades; Bragg $\left(V_{l}\right)$, Paranā $\left(V_{2}\right)$ e Santa Rosa $\left(V_{3}\right)$ cultivadas na presença do fos fato Alvorada $\left(\mathrm{T}_{2}\right)$. 
Alvorada. O fosfato natural superou estatisticamente a testemunha somente quando foi aplicado no solo com a acidez corrigida, is to $\bar{e}$, em $T_{2}$.

Esta vantagem a favor do fosfato solüvel se deve támbèm a sua maior solubilidade. As comparações entre $T_{1}, T_{2}$ e $T_{3}$ com $T_{4}, T_{5}$ e $T_{6}$ avaliam o efeito das formas de aplicação do corretivo da acidez na disponibilidade de fösforo. Este alemento é absorvido na sua quase totalidade pelo processo de dif $\underline{u}$ são que estä na dependência da superfície radicular segundo Bar ber e 01 son (1968), citados por MALAVOLTA (1976). Considerando se o efeito do Mn no desenvolvimento radicular conforme a discussão na Tabela 7, fica impedido de se atribuir qualquer influência das formas de aplicação do $\mathrm{Ca}(\mathrm{OH})_{2}$ na disponibilidade de fösforo.

\subsubsection{Fósforo do solo aos 30 dias de incu- bação}

Os dois tratamentos que receberam fosfato nat ral apresentaram teores mais elevados de $P$ do que os que recebe ram fosfato solúvel quando se empregou os extratores àcidos de Mehlich e Bray 2, resultados que confirmam os obtidos por FElT $\underline{0}$ SA (1978). O mesmo autor atribui tal fato à dissolução dos fos fatos naturais por esses extratores causando uma superestimação dos teores disponíveis do elemento.

Quando.se utilizou o mëtodo de 0lsen, os teores 
de fösforo foram superiores nos tratamentos com fosfato solüvel do que naqueles com fosfato Alvorada, reforçando mais uma vez os resultados de FEITOSA (1978). A natureza alcalina do extrator não tem o poder de dissolução dos fosfatos apatíticos, indicando teores de $P$ mais baixo que nos tratamentos com fosfato solúvel, como pode ser observado na Tabela 11.

o efeito das maneiras de aplicação do corretivo da acidez na solubilização do fosfato natural, pode ser observado na comparação de $T_{2}$ com $T_{5}$, e percebe-se que não houve diferença nos extratores àcidos, ao passo que atravēs do mētodo de olsen é evidente a influência da acidez do solo na solubilização do fosfato natural durante o período de incu vação. JUo e KANG (1979) ao estudarem a influência da calagem na solubilização de fosfatos de rocha, em solos africanos verificaram que onde não se corrigiu a acidez houve maior solubilização do foṣfato de rocha. 
Tabela 8 - Anālise de variância do P no solo aos 30 e 240 dias de incubaçāo, com desdobramento do nümero de graus de liberdade de tratamentos e da interação.

\begin{tabular}{|c|c|c|c|}
\hline & & QUADRADOS & MEDIOS \\
\hline CAUSA DA VARIAÇAOO & G.L. & $\begin{array}{l}\text { P do solo aos } 30 \\
\text { dias de incubação }\end{array}$ & $\begin{array}{l}\text { P do solo aos } 240 \\
\text { dias de incubação }\end{array}$ \\
\hline Tratamentos d. $E_{l}$ & 5 & $1.256,9420 * \star$ & $946,6925^{* \star}$ \\
\hline Tratamentos d. $E_{2}$ & 5 & $626,5985^{\star \star}$ & $525,9875^{* *}$ \\
\hline Tratamentos d. $E_{3}$ & 5 & $405,4535^{\star \star}$ & $61,8899^{\star \star}$ \\
\hline Extratores (E) & 2 & $864,7382 * \star$ & $2.338,2759^{\star \star}$ \\
\hline Resíduo & 54 & 3,1005 & 2,3055 \\
\hline C. V. $\%$ & & 8,1281 & 8,7153 \\
\hline
\end{tabular}


Tabela 9 - Anālise da variância do $P$ no solo aos 30 e 240 dias de incubação, com desdobramento do nümero de graus de liberdade de extratores e da interação.

\begin{tabular}{|c|c|c|c|}
\hline \multirow{2}{*}{ CAUSA DA VARIAÇĂO } & \multirow{2}{*}{ G.L. } & QUADRADOS & \multirow{2}{*}{$\begin{array}{l}\text { MEDIOS } \\
\text { P do solo aos } 240 \\
\text { dias de incubação }\end{array}$} \\
\hline & & $\begin{array}{l}\text { P do solo aos } 30 \\
\text { dias de incubação }\end{array}$ & \\
\hline Extratores d. $T_{1}$ & 2 & $22,9258^{* *}$ & $334,1430^{* *}$ \\
\hline Extratores d. $T_{2}$ & 2 & $1.558,9337^{* *}$ & $1.416,8153^{* *}$ \\
\hline Extratores $d \cdot T_{3}$ & 2 & $0,7583 n . s$ & $15,7980^{* *}$ \\
\hline Extratores d. $\mathrm{T}_{4}$ & 2 & $34,9680 * *$ & $433,2021^{* *}$ \\
\hline Extratores d. $T_{5}$ & 2 & $898,6487 * *$ & $1.664,2252^{* *}$ \\
\hline Extratores d. $T_{6}$ & 2 & $0,6475 \mathrm{n} . \mathrm{s}$ & $14,4078^{* *}$ \\
\hline Trat amentos & 5 & $1.653,9974 * *$ & $1.100,4438 * *$ \\
\hline Residuo & 54 & 3,1005 & 2,3055 \\
\hline
\end{tabular}


Tabela 10 - Teor de fösforo (mg/vaso) contido na parte aërea vegetal. Médias de quatro repetições e médias gerais de tratamentos e variedades.

\begin{tabular}{|c|c|c|c|c|c|}
\hline \multirow{2}{*}{ TRAT AMENTOS } & & \multicolumn{3}{|c|}{ VARIEDADES } & \multirow{2}{*}{$\begin{array}{l}\text { MEDIAS } \\
\text { - GERAIS DE } \\
\text { TRATAMENTOS }\end{array}$} \\
\hline & & BRAGG & PARANA & S. ROSA & \\
\hline $\mathrm{Ca}(\mathrm{OH})_{2}+\mathrm{F}$. monocálcico & $\left(T_{1}\right)$ & 19,61 & 19,32 & 16,68 & 18,54 \\
\hline $\mathrm{Ca}(\mathrm{OH})_{2}+\mathrm{F}$. Alvorada & $\left(T_{2}\right)$ & 10,55 & 9,04 & 11,60 & 10,40 \\
\hline $\mathrm{Ca}(\mathrm{OH})_{2}$ sem fosfato & $\left(T_{3}\right)$ & 5,98 & 3,52 & 6,46 & 5,32 \\
\hline F. monocālcico $+\mathrm{Ca}(\mathrm{OH})_{2}$ & $\left(T_{4}\right)$ & 11,31 & 11,96 & 13,52 & 12,26 \\
\hline F. Alvorada $+\mathrm{Ca}(\mathrm{OH})_{2}$ & $\left(T_{5}\right)$ & 6,13 & 6,14 & 4,84 & 5,70 \\
\hline Sem fosfato com $\mathrm{Ca}(\mathrm{OH})_{2}$ & $\left(T_{6}\right)$ & 3,42 & 2,66 & 2,13 & 2,74 \\
\hline MEDIAS GERAIS DE VARIEDAD & & 9,50 & 8,77 & 9,20 & \\
\hline
\end{tabular}

Tukey $5 \%$

D.M.S. para tratamentos dentro de variedades: 4,38

D.M.S. para variedades dentro de tratamentos: 3,58

D.M.S. para tratamentos (Geral) : 2,53

D.M.S. para variedades (Geral) : 1,46 
Tabela 11 - Fósforo do solo (ppm P) aos 30 dias de incubação em condiçöes de pH 6,5 (T1, T2 e $\left.T_{3}\right)$ e de $\mathrm{TH}_{5,0}\left(\mathrm{~T}_{4}\right.$, $T_{5}$ e $\left.T_{6}\right)$. Médias de quatro repetições e médias gerais de tratamentos e extratores.

\begin{tabular}{|c|c|c|c|c|c|}
\hline \multirow{2}{*}{\multicolumn{2}{|c|}{ TRATAMENTOS }} & \multicolumn{3}{|c|}{ EXTRATORES } & \multirow{2}{*}{$\begin{array}{l}\text { MEDIAS } \\
\text { GERAIS DE } \\
\text { TRATAMENTOS }\end{array}$} \\
\hline & & MEHLICH & BRAY - 2 & OLSEN & \\
\hline $\mathrm{Ca}(\mathrm{OH})_{2}+\mathrm{F}$. monocälci & $\left(T_{1}\right)$ & 29,00 & 24,25 & 26,09 & 26,45 \\
\hline $\mathrm{Ca}(\mathrm{OH})_{2}+\mathrm{F}$. Alvorada & $\left(T_{2}\right)$ & 47,30 & 34,19 & 8,76 & 30,08 \\
\hline $\mathrm{Ca}(\mathrm{OH})_{2}$ sem fosfato & $\left(T_{3}\right)$ & 6,37 & 5,97 & 6,84 & 6,39 \\
\hline F. monocälcico & $\left(T_{4}\right)$ & 32,37 & 26,55 & 29,92 & 29,61 \\
\hline F. Alvorada & $\left(T_{5}\right)$ & 44,12 & 32,67 & 14,96 & 30,58 \\
\hline Sem fosfato & $\left(T_{6}\right)$ & 6,72 & 6,52 & 7,30 & 6,85 \\
\hline \multicolumn{2}{|c|}{ MEDIAS GERAIS DE EXTRATORES } & 27,65 & 21,69 & 15,64 & \\
\hline
\end{tabular}

Tukey $5 \%$

D.M.S. para tratamentos dentro de extratores: 3,68

D.M.S. para extratores dentro de tratamentos: 3,00

D.M.S. para tratamentos (Geral) : 2,12

D.M.S. para extratores (Geral) $\div 1,23$ 
Tabela 12 - Fösforo do solo (ppm P) aos 240 dias de incubação. Médias de quatro repetições e médias gerais de tratamentos e extratores.

\begin{tabular}{|c|c|c|c|c|}
\hline \multirow{2}{*}{ TRATAMENTOS } & \multicolumn{3}{|c|}{ EXTRATORES } & \multirow{2}{*}{$\begin{aligned} & \text { MEDIAS } \\
\text { GERAIS DE } & \text { TRATAMENTOS }\end{aligned}$} \\
\hline & MEHLICH & BRAY - 2 & OLSEN & \\
\hline $\mathrm{Ca}(\mathrm{OH})_{2}+\mathrm{F}$. monocälcico $\left(T_{1}\right)$ & 28,56 & 26,29 & 11,72 & 22,19 \\
\hline $\mathrm{Ca}(\mathrm{OH})_{2}+\mathrm{F} \cdot$ Alvorada & 39,15 & 31,02 & 3,26 & 24,48 \\
\hline $\mathrm{Ca}(\mathrm{OH})_{2}$ sem fosfato & 5,73 & 6,21 & 2,55 & 4,83 \\
\hline F. monocālcico $+\mathrm{Ca}(\mathrm{OH})_{2}\left(\mathrm{~T}_{4}\right)$ & 28,98 & 27,06 & 10,40 & 22,15 \\
\hline F. Alvorada $+\mathrm{Ca}(\mathrm{OH})_{2}$ & 40,63 & 29,29 & 6,20 & 25,37 \\
\hline Sem fosfato com $\mathrm{Ca}(\mathrm{OH})_{2} \quad\left(\mathrm{~T}_{6}\right)$ & 6,56 & 7,15 & 3,32 & 5,68 \\
\hline MEDIAS GERAIS DE EXTRATORES & 24,93 & 21,17 & 6,24 & \\
\hline
\end{tabular}

Tukey $5 \%$

D.M.S. para tratamentos dentro de extratores: 3,17

D.M.S. para extratores dentro de tratamentos: 2,59

D.M.S. para tratamentos (Geral) : 1,83

D.M.S. para extratores (Geral): 1,06 
5.2.1.3. Fósforo do solo aos 240 dias de incubaçăo

Observando-se a Tabela 12 e a Figura 4 verifica-se que ao final deste período o fósforo do solo extraído pe los extratores em uso, teve um comportamento geral semelhante àquele encontrado aos 30 dias de incubação.

\subsubsection{Comparaçäo entre variedades}

A anälise da variância para o teor de fösforo contido na parte aérea, Tabela 2 , indica a inexistência de diferença significativa entre as variedades dentro de cada trata mento.

Embora o teste de Tukey na Tabela 10 , confirme a previsão feita pela anälise de variância, as comparações relativas da absorção de fósforo na figura 5 possibilita uma anä I ise sob outro prisma de observação.

Onde os fosfatos foram incubados em $\mathrm{pH} 6,5\left(\mathrm{~T}_{1}\right.$, $T_{2}$ e $T_{3}$ ), as absorçöes relativas de Bragg e Santa Rosa no fosfato Alvorada foram cerca de 1,6 vezes a testemunha ao passo que a variedade Paranā absorveu em torno de 2,4 vezes.

Onde os fosfatos foram incubados em $\mathrm{pH} 5$ ( $\mathrm{T}_{4}$, $T_{5}$ e $\left.T_{6}\right)$ a situação se repete, com sensirvel modificação ape nas na Santa Rosa que tendeu se aproximar da variedade Paraná. 


\subsubsection{Comparaçāo entre extratores}

A anālise de variância para o fósforo do solo somente não foi significativa no caso dos extratores dentro das testemunhas, aos 30 dias de incubação cujos resultados se acham na Tabela 9 .

5.2.3.1. Fósforo do solo aos 30 dias de incubação

A comparação entre as médias da Tabela 11 rẹ vela os métodos de Mehlich e de Olsen como os de maior poder de extração de fósforo nos tratamentos com fosfato solüvel. On de se utilizou fosfato natural os extratores obedeceram a seguinte colocação em ordem decrescente de extração: Mehlich, Bray-2 e $01 s e n .0$ ültimo método mostrou-se o menos eficaz na recuperação do fósforo onde se usou fosfato natural, não signi ficando contudo que seja o menos eficiente na estimativa do fósforo disponivel à planta. SFREDo et alii (1979) comparando cinco extratores em fosfato natural obteve menor capacidade de recuperação de $P$ com o método de Olsen do que Mehlich e Bray-2.

Nas testemunhas os extratores não diferiram entre si. 
Еたே

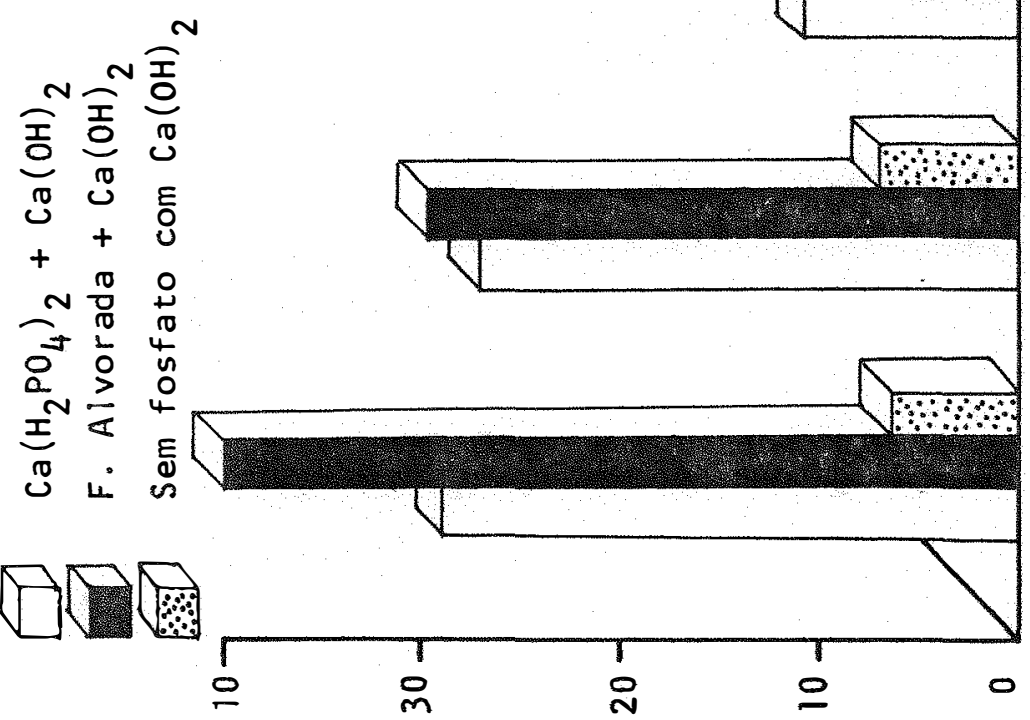

w] ${ }_{0}^{2}$

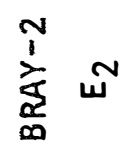

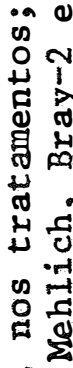

I $\quad$ i़ू

产 $w^{-}$

的

दु क्षे

.

요

a

-

0 is

N

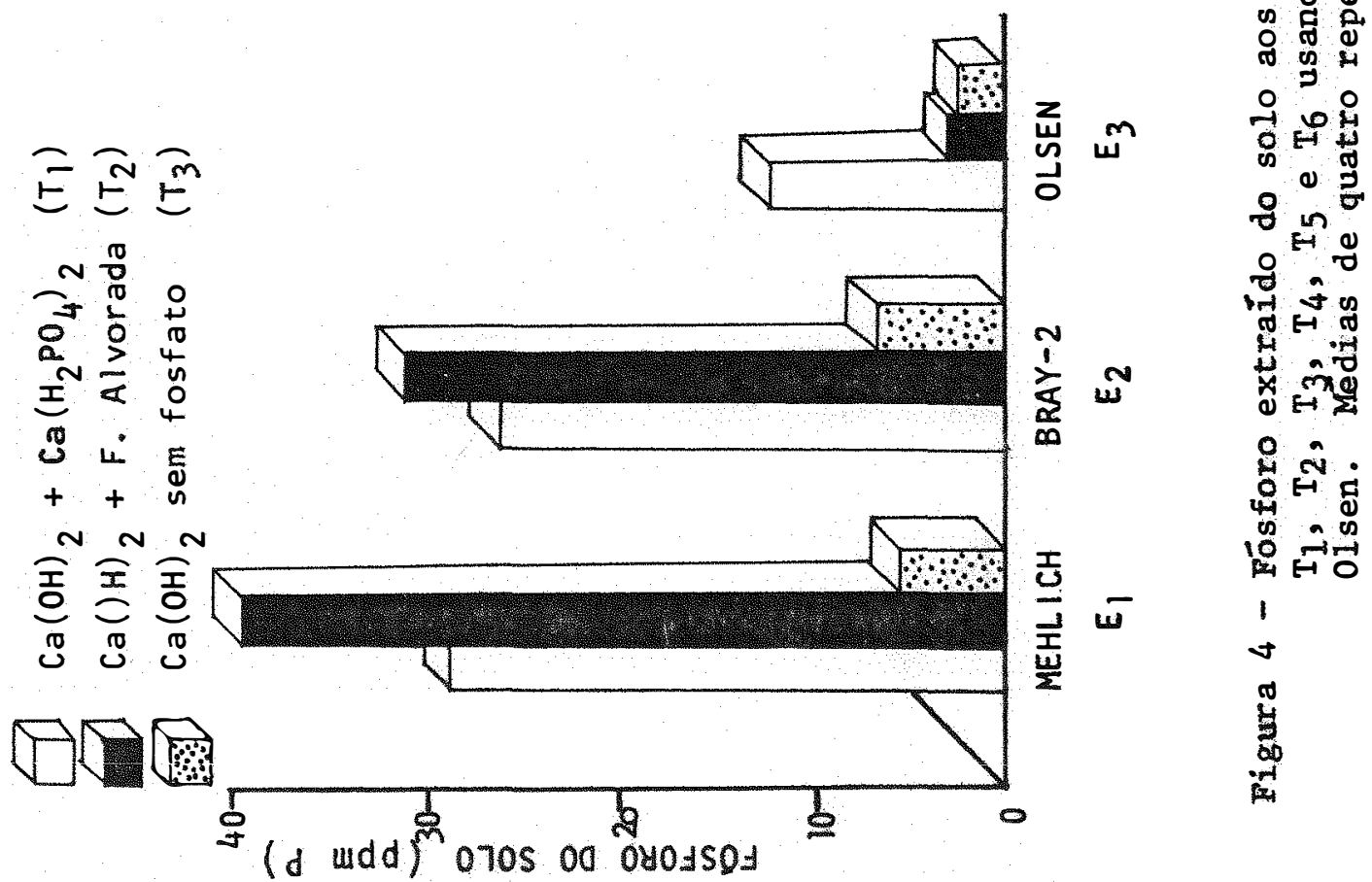



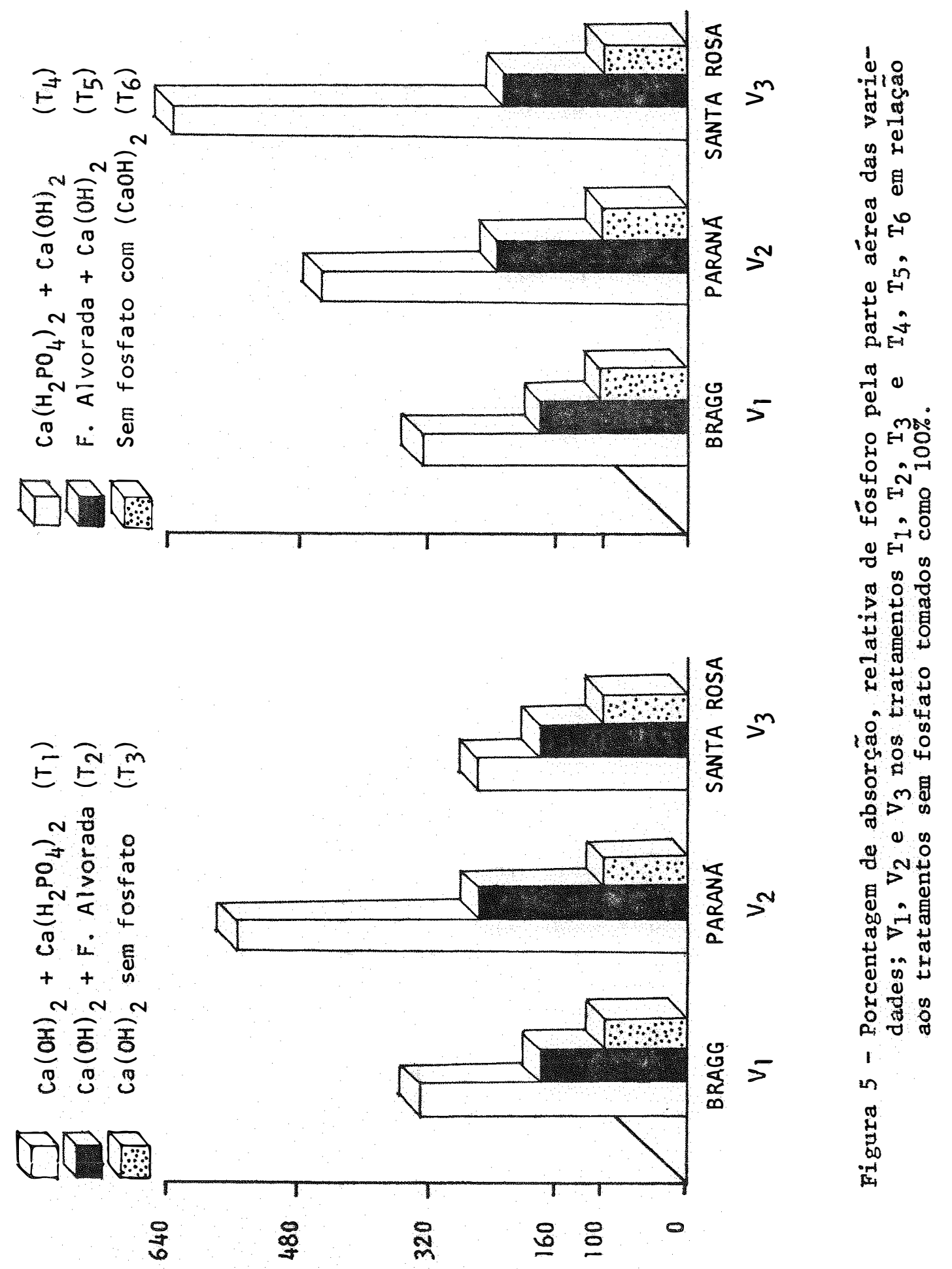

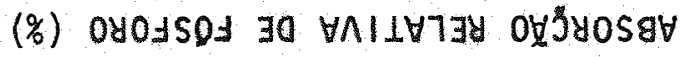


5.2.3.2. Fósforo do solo aos 240 dias de incubação

Comparando-se os extratores na Tabela 12 , nos tratamentos com fosfato natural a situação é idêntica àquela aos 30 dias de incubação, porēm, nos tratamentos $T_{1}, T_{3}, T_{4}$ e T6 houve um decrēscimo na extração de fósforo pelo método de Olsen neste periodo.

\subsection{Estudo da correlação entre extratores e produção.} de matéria seca

5.3.1. Matéria seca da parte aérea

Os gräficos das figuras 6 e 7 ilustram a ausente e inexpressiva correlação do fösforo extraído do solo com as produções de matēria seca da parte aërea das varieda des Bragg, Paraná e Santa Rosa, quando se utilizou os extratores de Mehlich e Bray-2. Estes mëtodos acusaram elevados teores de fösforo onde se usou fosfato natural, porém a planta pouco aproveitou, pois não houve correspondência na produção.

Multo embora o método de 01 sen tenha se mostrado o menos capaz em extrair fösforo (Tabela 12), foi ele que possibilitou a melhor correlação entre o fósforo do solo e a produção de matéria seca, é o que mostram os grä́ficos da Figura 8 . 
5.3.2. Matéria seca radicular

Uma apreciação das figuras 9,10 e 11 revela
que as correlaçōes com a matēria seca de raízes foi similar às
anteriores obtidas com a produção da parte aérea.




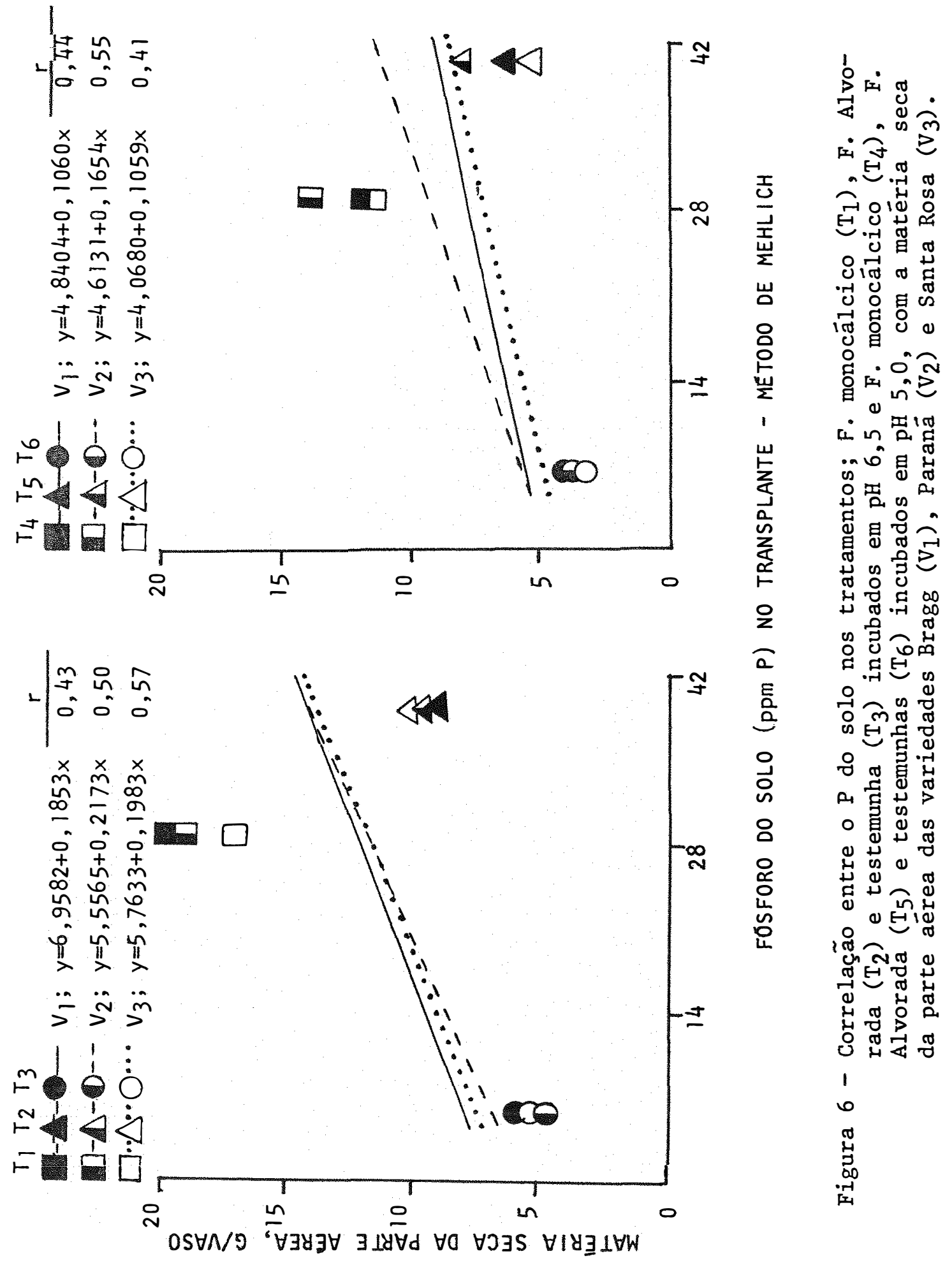




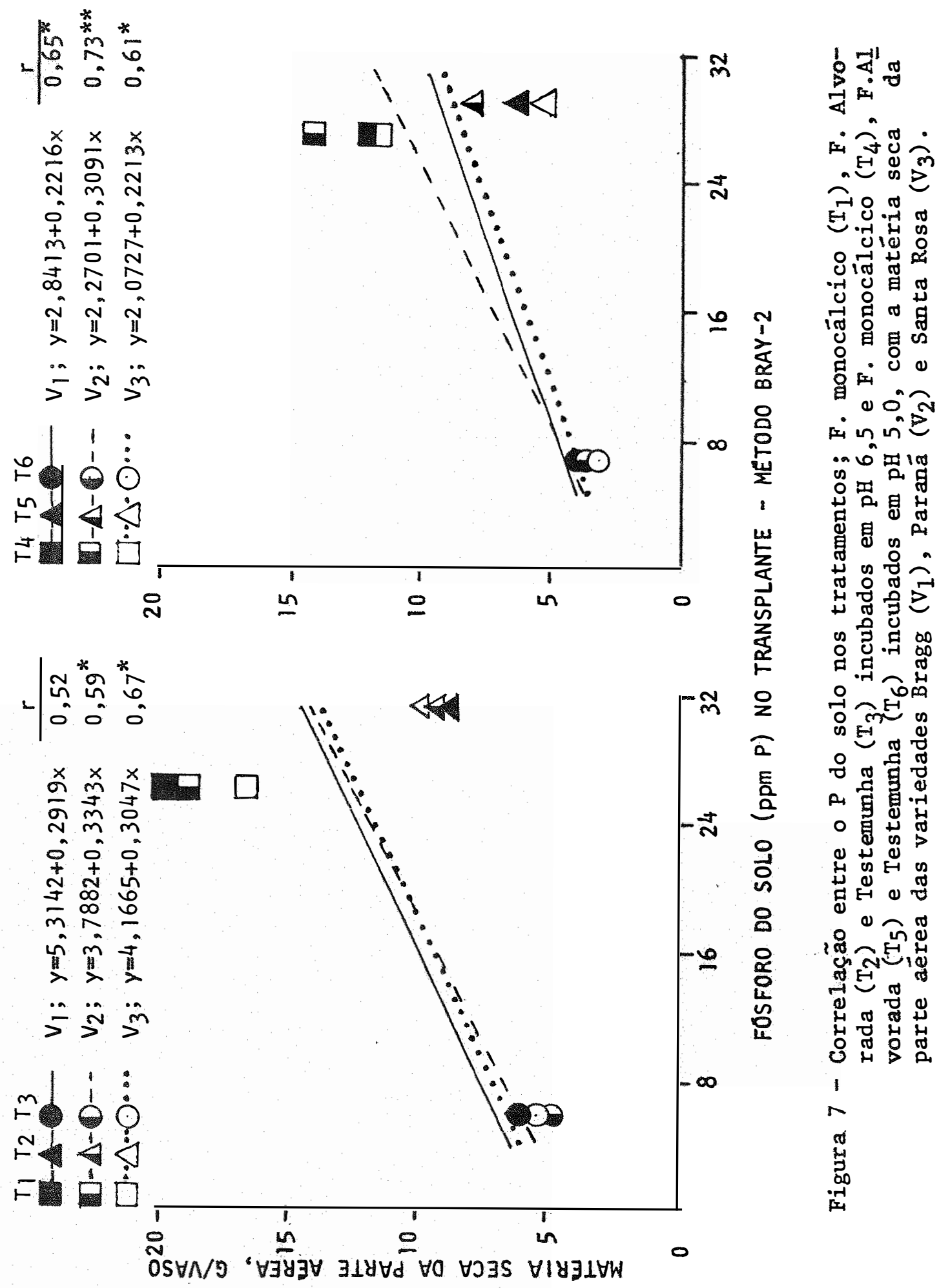



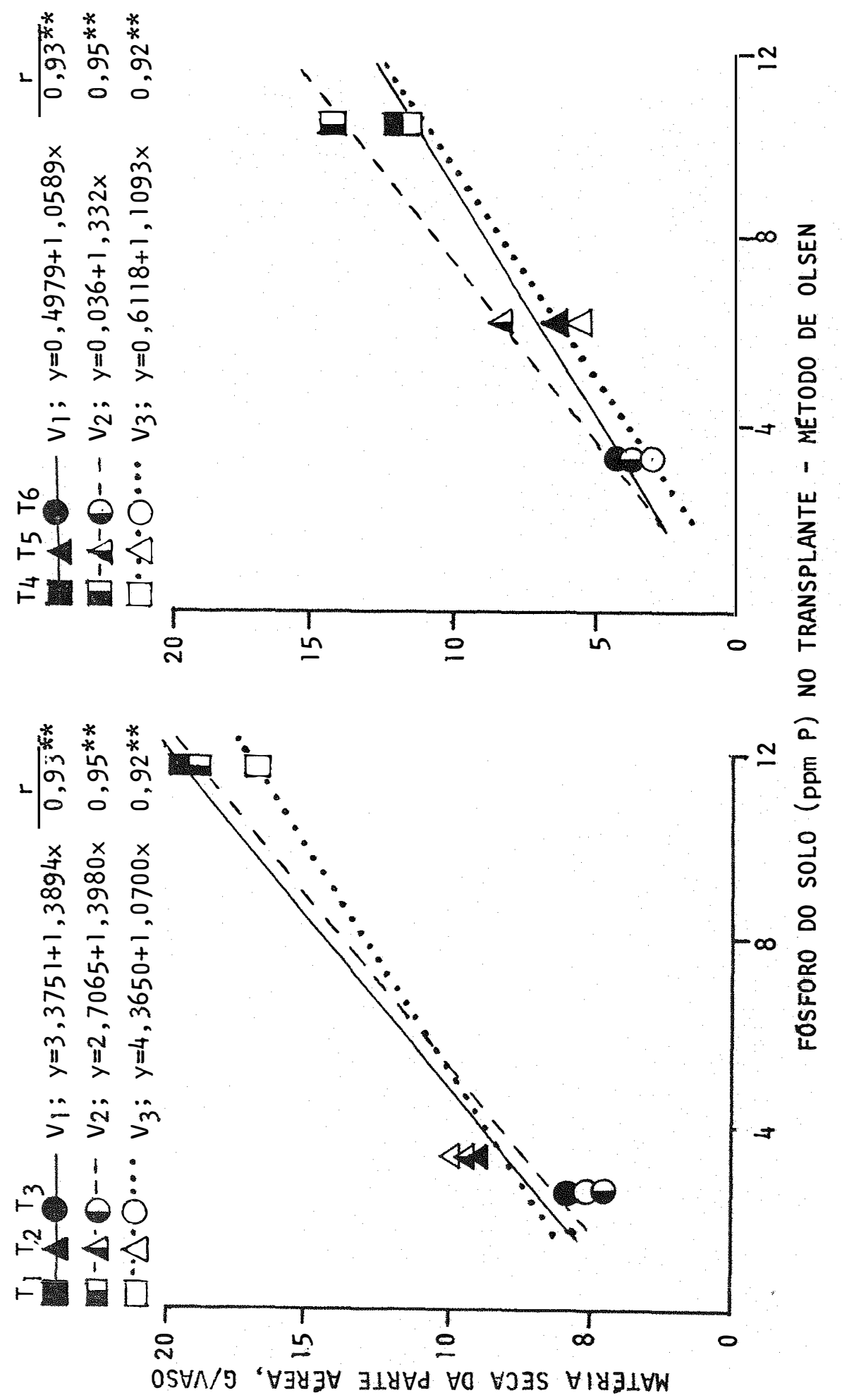

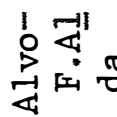

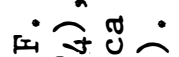

터

स्त $0 . \pi$

-

ठात्

-

成吉

음 吕的

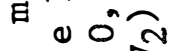

1

मi in in

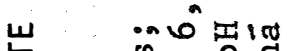

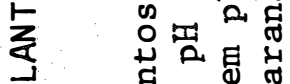

a

良

寻易的

出。 营

幽雚已

क సै.

$0 S \forall N / 9$ " $\forall \exists Y \exists \forall \exists I Y \forall d \quad \forall 0$ VJaS $\forall 14 \exists \perp \forall W$ 


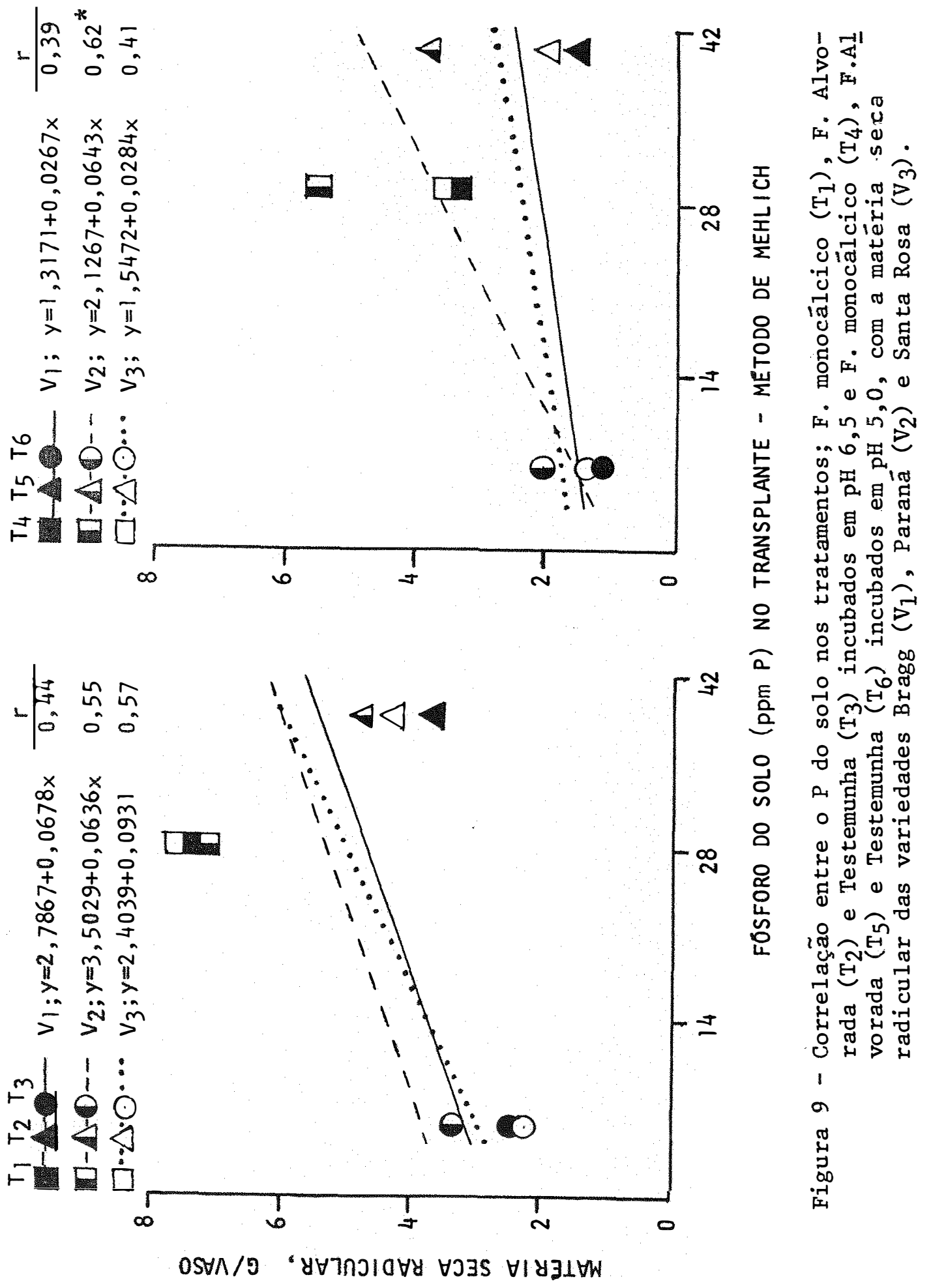




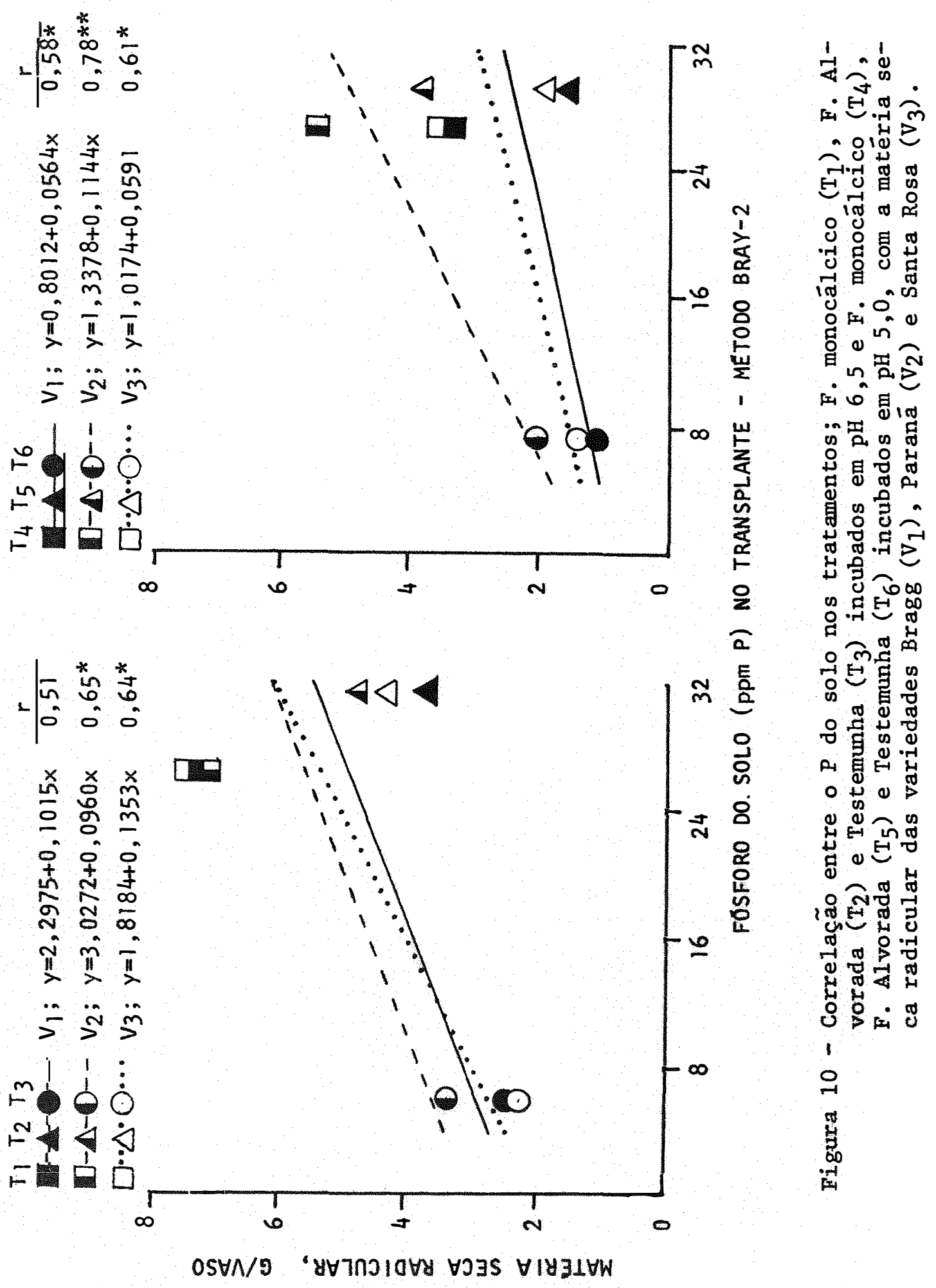




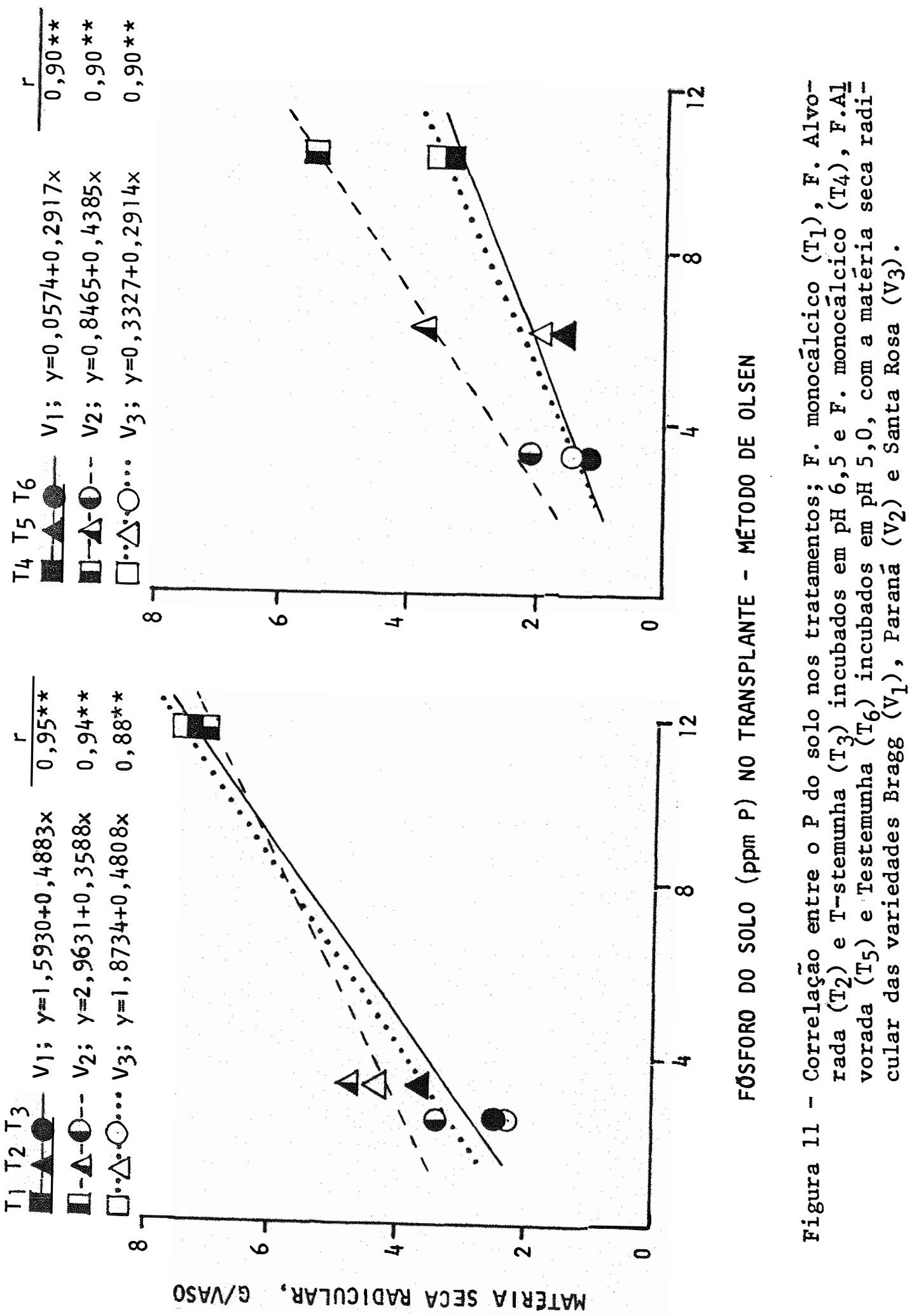


6. CONCLUSOES

Para as condições em que o trabalho experi mental foi conduzido pode-se enumerar as seguintes conclusões:

6.1. A variedade Paraná apresenta maior sensibilidade ao elemento fósforo do que as variedades Bragg e Santa Rosa.

6.2. O fosfato natural empregado (fosfato Alvorada) é menos eficiente que o fosfato solúvel (fosfato monocál cico) quanto ao fornecimento de fósforo para as três variedades estudadas.

6.3. Existe influência da acidez do solo no aumento da so lubilização do fosfato natural determinada através do método de 0lsen.

6.4. Quanto aos extratores de fósforo, os métodos de Mehrich e Bray-2 são mais potentes na solubilização do fosfato natural do que o método de olsen, porém, 
este apresenta as melhores correlações com a produ ção vegetal de matéria seca. 


\section{SUMMARY}

A greenhouse pot-experiment was conducted with following purposes: a) To study the phosphorus uptake differences among soybeans varieties (Glycine max (L.) Merril). b) To compare the phosphorus supplying effectiveness of rock phosphate (Alvorada Phosphate) and soluble phosphate (Monocalcium Phosphate) to the plant. c) To verify the influence of soil acidity on the natural phosphate solubilization. d) To test the following P-extractants: Mehlich, Bray-2 and 01 sen about the best correlation with the vegetal dry matter production.

The experiment was conducted using a Podzölico Vermelho Amarelo, variação Piracicaba, serie Godinhos Soll (PVA) with the treatments: Monocalcium Phosphate $\left(T_{1}\right)$, Alvorada Phosphate $\left(T_{2}\right)$ and the check $\left(T_{3}\right)$, all incubated at $\mathrm{pH} 6.5$; Monocalcium Phosphate $\left(\mathrm{T}_{4}\right)$, Alvorada Phosphate $\left(\mathrm{T}_{5}\right)$ and the check ( $\left.T_{6}\right)$, all incubated at $\mathrm{pH} 5.0$ followed by imediate correction of soil acidity for planting. It was planted three 
soybeans varieties: Bragg $\left(V_{1}\right)$, Parana $\left(V_{2}\right)$ and Santa Rosa $\left(V_{3}\right)$. The phosphorus extracting methods were Mehlich, Bray-2 and 01 sen $(\operatorname{modified})$.

\begin{abstract}
Besides chemical analysis in plants and soll, it was proceeded biological evaluations through plants height, number of inter-nodes, and weights of stems, leaves and roots after 62 days of emergence.
\end{abstract}

The data obtained under the experimental conditions permitted the following conclusions:

- Paraná variety is more sensible to phosphorus than the others studied.

- Alvorada Phosphate is less efficient in supplying phosphorus to plants than Monocalcium Phosphate.

- The 0lsen method (modified) best correlects with vegetal dry matter production.

- The soll acidity increases the solubilization of Alvorada Phosphate. 


\section{LITERATURA CITADA}

ABRÃo, J.R., 1975. Efeito da aplicação de fösforo de diferen tes fosfatadas sobre a produção de soja. Ata da III Reunião Conjunta de Pesquisa da Soja - RS/SC. Porto Alegre RS . $89-90$.

AMES, J.W. e K. KITSUTA, 1931. Availability of rock phosphate as indicated by Phosphorus assimilation of plants. Journal of the American Society of Agronomy. New York, 103-122.

ANDA, 1975. Manual de Adubaqão. 22. Ed. São Paulo, ASsociaÇAO NACIONAL PARA DIFUSÃO DE ADUBOS, $346 \mathrm{p}$.

ANGHINON I, 1., 1974. Avaliação da disponibililade do fösforo para os solos do Rio Grande do Sul. Agronomia Sul Riograndense. Porto Alegre, 10:127-136.

ARMIGER, W.H. e F. MAURICE, 1957. The plant availability of various sources of phosphate rock. Soil soience society Proceedings. Madison, Wisconsin, 21:183-188. 
BARTHOLOMEU, R.P., 1937. Availability of phosphate rocks in soils of varying degrees of acidity. Journal of the American Society of Agronomy. New York, 293-298.

BATAGLIA, O.C.; H.A.A. MASCARANHAS e O. TISSELLI FILHO, 1977. Competição mineral das sementes de nove cultivares de soja. Bragantia. Campinas, $36: X L V I I-L$.

BENNETT, O.L.; L.E. ENSMINEER e R.W. PEARSON, 1957. The availabitity of phosphorus in various sources of rock phosphate as shown by greenhouse studies. Soils Science Society Proceedings. Madison, Wisconsin, 22:521-524.

BRAGA, J.M., 1970. Boletim Têcnico n: 21 - Universidade Fede ral de Viçosa, $61 \mathrm{p}$.

BRAGA, N.R.; H.A.A. MASCARANHAS; C.T. FEITOSA; R. HIROCE B. van RAIJ, 1978. Efeito de diversos fosfatos sobre o crescimento e produção de soja. XIII Reunião da Sociedade Brasizeira de Ciência do Sozo. Goiania, 9 p.

BRASIL SOBRINHO, M.O.C.; F.A.F. MELLO E T. COURY, 1965. Estudo sobre a solubilidade de fosfatos em ácido citrico a $2 \%$ Anais da ESALQ. Piracicaba, XXII:104-109.

BRAY, R.H. e L.T. KURTZ, 1945. Determination of total, organic and avallable forms of phosphorus in soils. Soir Sci, 59: $39-45$. 
CAMPELO, G.J.; J. MIELNICZUK e P.R.F. SILVA, 1975. Efeito na calagem e da adubação fosfatada no rendimento de grãos, componentes do rendimento e outras características agronômicas em duas cultivares de soja. Ata da III Reunião Conjunta de Pesquisa da Soja, RS/SC. Porto Alegre. P. 136.

CHIEN, S.H., 1978. Interpretation of Bray-I-Extractable phos phorus from acid soil treated with phosphate rocks. Soit Science. $126: 34-39$.

CORDEIRO, D.S.; D. POTTKER; C.M. BORKERT; G.J. SFREDO; A.N. MESQUITA; R.C. DITRICH e J.B. PALHANO, 1979. Efeito de niveis e fontes de fósforo na produção e no rendimento econô mico da soja na Região de Dourados (MS). Revista Brasizeira de Ciência do Solo. Campinas, 3:100-105.

DEMATTE, J.L.K.; A.C.MONIZ E J.E.S.PESSOTTI, 1977. SOIOS originados de sedimentos do grupo geológico Estrada Nova, Municipio de Piracicaba. |1-Classificação. Revista BrasiZeira de Ciência do Solo. Campinas, 147-51.

DE MOOY, C.J.; J. PESEK E E. SPALDON, 1973. Mineral nutrition. In: HAMILTON, H., Editor SOYBEANS: Improvement, Production and Uses. Madison, Wisconsin, USA, American Society of Agronomy. $\quad 16: 267-352$.

EPSTEIN, E., 1975. Nutrigão Mineral das Plantas - Principios e Perspectivas. Trad. Notas de E. Malavolta. Livros Técnicos e Clentificos Ed. A.S. e Ed. da USP, São Paulo, 341 P. 
FARIA, C.M.B. J.R. PEREIRA., 1979. Influência de nirveis e épocas de aplicação de fósforo na produção de culturas em um sistema de rotação e nos teores de fósforo de dois solos do Vale do Submédio São Francisco. Revista Brasileira de Ciência do Solo. Campinas, 3:97-100.

FEITOSA, C.T. e B. van RAlJ, 1976. Influência da natureza de fosfatos aplicados a dois solos no fósforo solüvel em extratores quimicos e disponivel para trigo e milho. In: Congresso Brasileiro de Ciênoia do Solo, IV , Campinas-sP Soc. Bras. Ciência do Solo. p. 215-220.

FEltosa, C.T., 1978. Avaliação da disponibilidade do fósforo aplicado ao solo na forma de diferentes fosfatos. Piracicaba, ESALQ/USP, 81 p. (Tese de Mestrado).

FÜLEKY, Gy., 1978. Available phosphorus content of soll affected by $P$ fertilization and its change in time. Commun. in Soil Science and Plant Analysis. 9:851-863.

GOMES, F.P., 1966. Curso de Estatistica Experimental. Gräfica Benetti Ltda-São Paulo. $404 \mathrm{p}$.

GOEPPERT, C.F., 1975. Efeito da aplicação de fósforo em dị ferentes fontes fosfatadas sobre a produção de soja. In: Ata da III Reunião Conjunta de Pesquisa da Soja, RS/SC. Porto Alegre-RS, p. 119. 
GOEPFERT, C.F., 1975. Experimentos de fósforo em adubação de correção e de manutenção na cultura da soja. In: Ata da III Reunião Conjunta de Pesquisa da Soja, RS/SC. Porto Alegre, p. 123.

gOepfert, C.F.; E. HILGERT; R.L. de MOURA; A. TEDeSCO e 0. SA LIM, 1976. Avaliação da eficiència de cinco adubos fosfatados em três solos äcidos do Rio Grande do Sul. Agronomia sul Riograndense. Porto Alegre, 12179-188.

HANSON, R.G., 1979. Soybeans need phosphorus for adequate nodulation. Better Crops with Plant Food. p. 26-27.

HORTENSTINE, C.C., 1966. Phosphorus fixation and phosphorus fraction in sandy soils. Soils and Crop Science Society of Florida. Gainesville-Florida, USA, 26:136-142.

INFORZATO, R. e H.A.A. MASCARANHAS, 1969. Estudo do sistema radicular da soja (Glycine $\max$ (L.) Merril) em solo latosso lo roxo adubado ou sem adubo. Bragantia. Eampinas, 28: $175-180$.

JUO, A.S.R. A B. T. KANG, 1979. Effect of liming on the availability of three rock phosphate sources in two West African Ultissols. Commun. in Soil Science and Plant Anatysis. Now York, 10:993-1003.

KAMPRATH, E.J., 1976. Phosphorus fixation and availabllity in high weathereo soils. IV Simposio sobre o Cerrado. São Pau10-EDUSP, 38:333-347. 
KOL ING, J.; E.R. HILGERT; J.R..J. FREIRE; J.S. PEREIRA N.G. MENDES, 1976. Comportamento de variedades de soja em resposta à calagem e adubações fosfatadas e potässica4: ano. IV Reunião Conjunta de Pesquisa da Soja, RS/SC. Santa Maria - RS.

LARSEN, S., 1967. Soil phosphorus. In: Norman, A.G. Editor. Advances in Agronomy. New York, American Society of Agronomy. $19: 151-210$.

LEPSH, I.F. e S.W. BUOL, 1974. Investigation in an 0xisolUltisol in Säo Paulo State, Brazil. Soil Science Society of America Proceedings. Madison, Wisconsin, 38:491-496.

LUTZ, J.A. Jr., 1971. Comparison of partially acidulated rock phosphate and concentrated superphosphate as sources of phosphorus for corn. Agronomy Journal. Madison, Wisconsin, $63: 919-922$.

LUTZ, J.A. Jr., 1973. Effect of partially acidulated rock phosphate and concentrated superphosphate on yield and chemical composition of alfafa and orchardgrass. Agronomy Journaz, Madison, Wisconsin, 65:286-289.

MALAVOLTA, E.; H.P. HAAG; F.A.F. Mello e M.O.C. BRASIL SOBRINHO, 1974. Nutrigão Mineral e Adubagão de Plantas Cultivadas. Livraria Pioneira Editora. $727 \mathrm{p}$.

MALAVOLTA, E., 1976. Nutricão de plantas e Fertilidade do So20. São Paulo, Ed. Agronômica Ceres Ltda. 528 p. 
MASCARANHAS, H.A.A.; S. MIYASAKA; N.R. BRAGA; M.A.C. MIRANDA e 0. T. FILHO, 1977. Calagem e adubação da soja. In: FUNDAGÃo CARGIL. A Soja no Brasil Central. p. 87-138.

MASCARANHAS, H.A.A.: e R.A.S. KIIHL, 1974. Observações preliminares sobre o efeito da adubação fosfatada na produção de soja em Latossolo Roxo distrófico. Bragantia. Campinas, $33: L X V I 1-L X X$.

MCLEAN, E.0. e R.W. WHEELER, 1964. Partially acidulated rock phosphate as a source of phosphorus to plants: I. Growth chamber studies. Soils Science Society Proceedings. Madison, Wisconsin. p. 545-550.

MCLEAN, E.0.; R.W. WHEELER e J.D. WATSON, 1965. Partially acidulated rock phosphate as a source of phosphorus to plants: growth chamber and field corn studies. Soils Science Society Proceedings. Madison, Wisconsin, 29:625-628.

MOURA, R.L.L. de; C.F. GOEPFERT; J. FERES E E.R. HILGERT, 1976. Comportamento de linhagens de soja em diferentes niveis de fertilidade em solo Passo Fundo. IV Reuniäo Conjunta de Pesquisa de Soja RS/SC. Santa Maria.

MUzILli, O. e J.B. PALhano, 1976. Curvas de respostas da cultura de soja à adubação fosfatada e potässica em solos do Es tado do Paraná. Informe Preliminar. Programa Soja do IAPARLondrina. 
NELSON, W.L.; A. MEHLICH e E. WINTERS, 1953. The development evaluation an use of soll testes for phosphorus avallability. In: Pierre \& Norman, Eds. - Soil and Fertilizer Phosphorus. Agronomy, $\quad 4: 153-188$.

NICHOLS, J.D.; G.M. PHIBBS e L.W. REED, 1960. Effect of nitrogen sulphur, and lime on utilization of rock phosphate by alfafa. Agronomy Journal. Madison, Wisconsin, 52:254-257.

NOVAIS, R.F. E E.J. KAMPRATH, 1979. Fösforo recuperado em três extratores quimicos como função do fósforo aplicado no solo e do "Fator Capacidade". Revista Brasileira de Ciência do So20. Campinas, $3: 41-46$.

OLSEN, S.; C.V. COLE; F.S. WATANABE e L.A. DEAN, 1954. Estimation of available phosphorus in soils by extraction with sodium bicarbonate. USDA (Circ. 939).

PAIVA LIMA, L.A.; C. VIEIRA; T. SEDIYAMA E C.S. SEDIYAMA, 1974. Resposta diferencial de quatro variedades de soja à adubação fosfatada e potässica, em três localidades do Estado-de Minas Gerais. Experientiae. Viçosa, 17:64-83.

PEREIRA, J.R. e C.M.B. FARIA, 1978. Disponibilidade de fósforo, aplicado em um vertissolo do mëdio são Francisco, avaliada por métodos químicos. Revista Brasileira de Ciência do so 20. Campinas, $2: 125-128$.

RANZANI, G.; O. FREIRE E T. KINJO, 1966. Carta de Solos do Municipio de Piracicaba. $85 \mathrm{p}$. (mimeografado). 
ROSCOE, E.Jr.; M.A. QUARDER e E. TRVOG, 1955. Rock phosphate availability as influenced by soil pH Soils Science society Proceedings. Madison, Wisconsin, p. 484-487.

SFREDO, G.J.; C.M. BORKERT; D.S. CORDEIRO, J.B. PALHANO R.C. DITTRICH, 1979. Comparação de cinco extratores de fós foro do solo, considerando-se o tempo de incorporação de três adubos fosfatados. Revista Brasileira de Ciência do solo. Campinas, $3: 111-115$.

TERMAN, G.L.; E.C. MORENO e 0. GLEN, 1964. Acidulation of phosphate rock in soil. Soils Science Society Proceedings. Madison, Wisconsin, p. 104-107.

Van RAIJ, B., 1978. Seleção de métodos de laboratörio para avaliar a disponibilidade de fösforo em solos. Revista Bra sileira de Ciência do Solo. Campinas, 2:1-9.

VIANNA, A.C.T.; H.D. CASALINHO e M.0. MACHADO, 1977. Estudo do comportamento da soja diante da aplicação de värias fontes de adubos fosfatados em solo vermelho amarelo podzölico. V Reunião Conjunta da Pesquisa da Soja da Região Sul. Pelotas, RS.

VOLK, G.W., 1943. Availability of rock and other phosphate fertilizers as influenced by lime and form of nitrogen fertilizer. Journal of the American Society of Agronomy. New York, 36:47-56. 
VOLKWEISS, S.J. e B. Van RAIJ, 1977. Retençäo e disponibilidade de fósforo em solo. IV Simpósio sobre o Cerrado Bases para a Utiliząão Agropecuária. Belo Horizonte, 317332. 
A PENDICE 
Tabela 1 - Teores médios porcentuais de alguns macronutrientes no tecido foliar das variedades de soja nos tratamentos de solo.

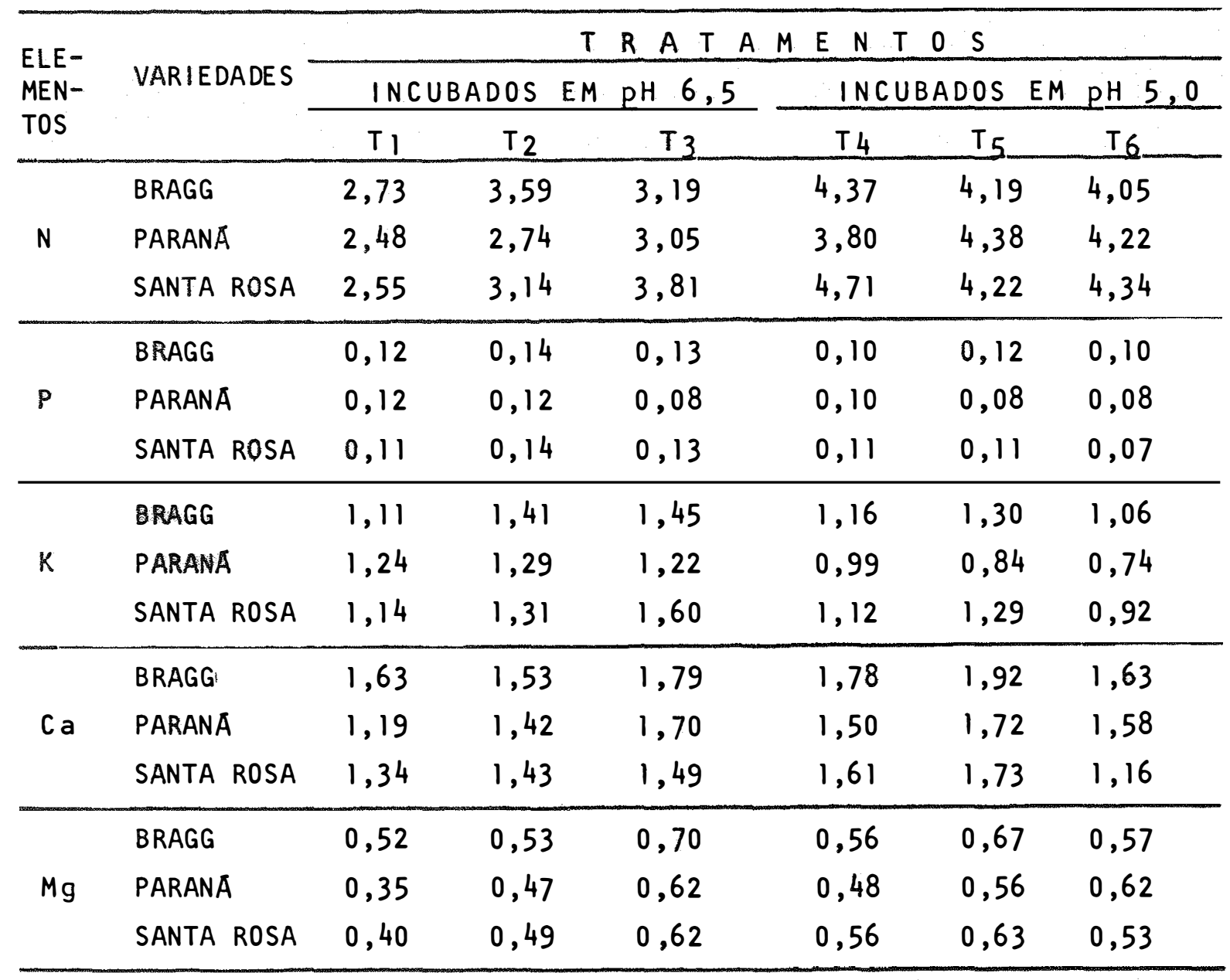

$T_{1}$ e $T_{4}:$ Fosfato Monocálcico

$T_{2}$ e $T_{5}$ : Fosfato Alvorada

$T_{3}$ e $T_{6}$ : Testemunhas 
Tabela 2 - Teores médios (ppm) de alguns micronutrientes no tecido foliar das variedades de soja nos tratamentos de solo.

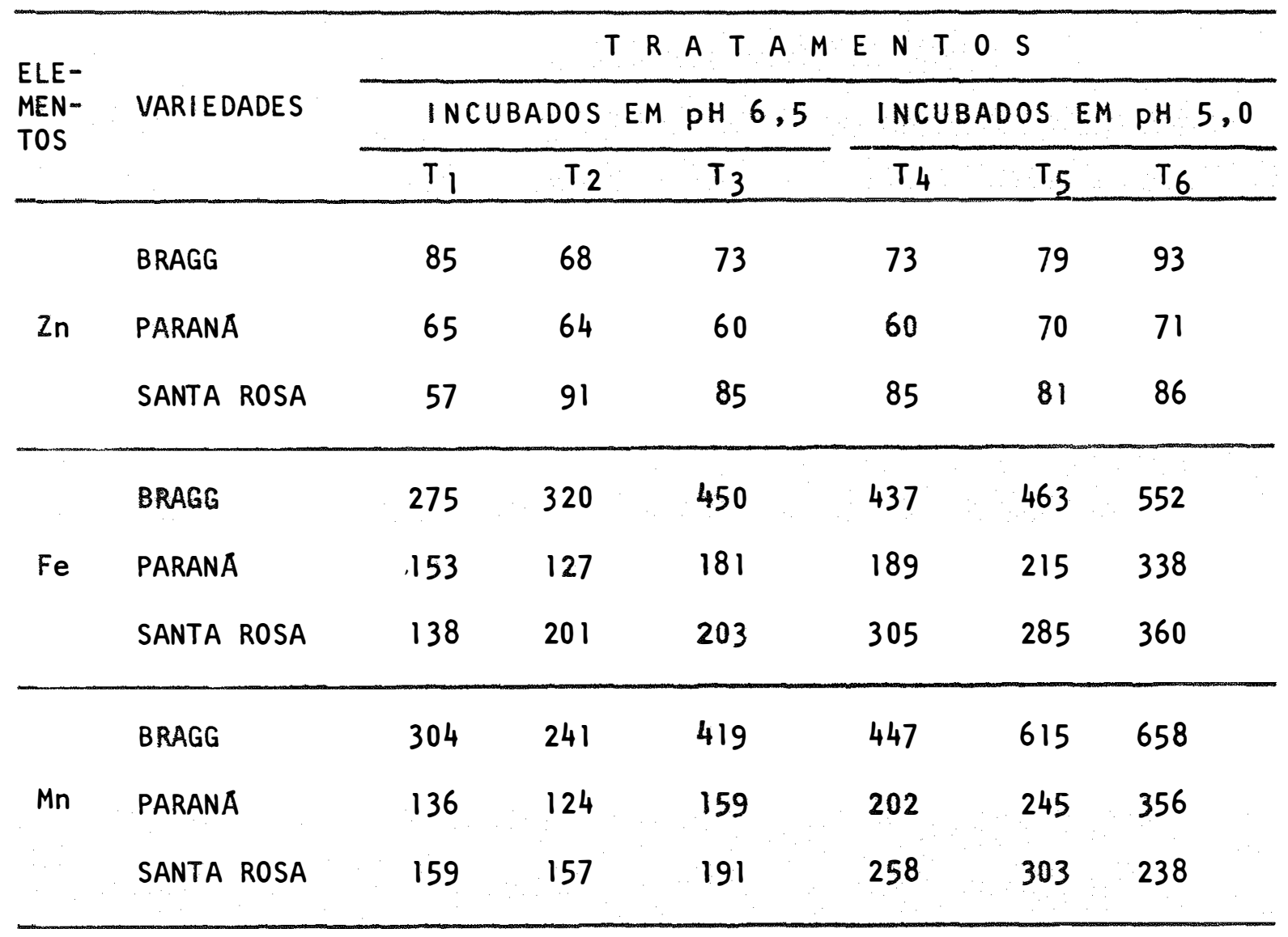

$T_{1}$ e $T_{4}$ : Fosfato monocälcico

$T_{2}$ e $T_{5}$ : Fosfato Alvorada

$T_{3}$ e $T_{6}:$ Testemunhas 
Tabela 3 - Teores mëdios porcentuais de alguns macronutrientes no caule das variedades de soja nos tratamentos de solo.

\begin{tabular}{|c|c|c|c|c|c|c|c|c|}
\hline \multirow{3}{*}{$\begin{array}{l}\text { ELE - } \\
\text { MEN - } \\
\text { TOS }\end{array}$} & \multirow{3}{*}{ VARIEDADES } & \multicolumn{7}{|c|}{ T R A T A M E T O S } \\
\hline & & \multicolumn{2}{|c|}{ INCUBADOS } & \multicolumn{2}{|c|}{ EM pH 6,5} & \multicolumn{2}{|c|}{ INCUBADOS EM } & \multirow{2}{*}{$\frac{p H 5,0}{T_{6}}$} \\
\hline & & $T_{1}$ & $\mathrm{~T}_{2}$ & & $\mathrm{~T}_{3}$ & $T_{4}$ & $T_{5}$ & \\
\hline \multirow{3}{*}{ N } & BRAGG & 1,43 & 2,26 & & 3,05 & 3,48 & 3,59 & 4,35 \\
\hline & PARANA & 0,94 & 1,73 & & 3,18 & 2,88 & 3,32 & 3,85 \\
\hline & SANTA ROSA & 1,19 & 1,34 & & 2,90 & 2,85 & 3,54 & 4,56 \\
\hline \multirow{3}{*}{$P$} & BRAGG & 0,07 & 0,06 & & 0,06 & 0,06 & 0,06 & 0,05 \\
\hline & PARANA & 0,07 & 0,07 & & 0,06 & 0,06 & 0,06 & 0,04 \\
\hline & SANTA ROSA & 0,07 & 0,08 & & 0,11 & 0,07 & 0,06 & 0,05 \\
\hline \multirow{3}{*}{ K } & BRAGG & 0,71 & 1,02 & & 0,90 & 0,60 & 0,94 & 0,92 \\
\hline & PARANA & 0,75 & 0,91 & & 0,71 & 0,49 & 0,51 & 0,50 \\
\hline & SANTA ROSA & 0,85 & 00,95 & & 1,14 & 0,76 & 0,92 & 0,74 \\
\hline \multirow{3}{*}{$\mathrm{Ca}$} & BRAGG & 0,69 & 0,96 & & 0,99 & 0,89 & 0,96 & 0,92 \\
\hline & PARANA & 0,65 & 0,65 & & 1,00 & 0,74 & 0,87 & 0,81 \\
\hline & SANTA ROSA & 0,77 & 0,93 & & 1,15 & 0,92 & 0,95 & 0,83 \\
\hline \multirow{3}{*}{$\mathrm{Mg}$} & BRAGG & 0,40 & 0,54 & & 0,49 & 0,51 & 0,57 & 0,58 \\
\hline & PARANA & 0,35 & 0,34 & & 0,43 & 0,40 & 0,44 & 0,46 \\
\hline & SANTA ROSA & 0,33 & 0,39 & & 0,48 & 0,41 & 0,42 & 0,38 \\
\hline
\end{tabular}


Tabela 4 - Teores médios (ppm) de alguns micronutrientes no caule das variedades de soja nos tratamentos de solo.

\begin{tabular}{|c|c|c|c|c|c|c|c|}
\hline \multirow{3}{*}{$\begin{array}{l}\text { ELE - } \\
\text { MEN - } \\
\text { TOS }\end{array}$} & \multirow{3}{*}{ VARIEDADES } & \multicolumn{6}{|c|}{ 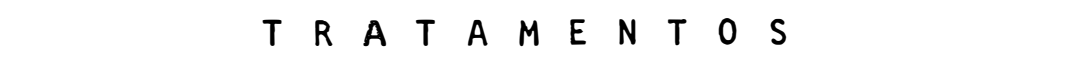 } \\
\hline & & \multicolumn{2}{|c|}{ I NCUBADOS e } & $n \mathrm{pH} 6,5$ & \multicolumn{2}{|c|}{ INCUBADOS em } & \multirow{2}{*}{$\frac{\mathrm{pH} 5,0}{\mathrm{~T}_{6}}$} \\
\hline & & $T_{1}$ & $\mathrm{~T}_{2}$ & $T_{3}$ & $T_{4}$ & $T_{5}$ & \\
\hline \multirow{3}{*}{$\mathrm{Zn}$} & BRAGG & 14,75 & 29,50 & 27,75 & 16,50 & 28,00 & 28,00 \\
\hline & PARANÅ & 15,50 & 19,00 & 28,50 & 18,00 & 18,00 & 21,75 \\
\hline & SANTA ROSA & 24,25 & 19,00 & 43,75 & 22,25 & 28,75 & 38,00 \\
\hline \multirow{3}{*}{$\mathrm{Fe}$} & BRAGG & 66,25 & 76,50 & 85,50 & 96,75 & 112,25 & 143,25 \\
\hline & PARANA & 48,75 & 47,50 & 69,00 & 69,50 & 62,50 & 77,25 \\
\hline & SANTA ROSA & 64,75 & 47,00 & 92,50 & 62,75 & $7 a, 75$ & 95,50 \\
\hline \multirow{3}{*}{$M n$} & BRAGG & 59,25 & 61,75 & 84,75 & 88,50 & 215,00 & 386,75 \\
\hline & PARANÅ & 32,50 & 26,50 & 28,75 & 50,50 & 63,25 & 132,00 \\
\hline & SANTA ROSA & 33,75 & 26,25 & 63,00 & 76,00 & 94,25 & 143,00 \\
\hline
\end{tabular}


Tabela 5 - Teores criticos de nutrientes contidos nas folhas mais jovens e maduras de soja no final de floraçäo (J.8. JONES, 1966 a 1968).

\begin{tabular}{|c|c|c|c|c|c|}
\hline Elementos & Deficiente & Baixo & Suficiente & Alto & Excesso \\
\hline$N$ & 4,00 & $4,0-4,5$ & $4,51-5,50$ & $5,51-3,0$ & $>7.0$ \\
\hline$P$ & 0,15 & $0,16-0,25$ & $0,26-0,50$ & $0,5-0,8$ & 0,8 \\
\hline$k$ & 1,25 & $1,12-1,70$ & $1,71-2,50$ & $2,51-2,75$ & 2,75 \\
\hline $\mathrm{Ca}$ & 0,20 & $0,21-0,35$ & $0,36-2,00$ & $2,01-3,00$ & $>3,00$ \\
\hline $\mathrm{Mg}$ & 0,10 & $0,11-0,25$ & $0,26-1,00$ & $1,01-1,50$ & $>1,51$ \\
\hline Mn & 14 & $15-20$ & $21-100$ & $101-250$ & 250 \\
\hline $\mathrm{Fe}$ & 30 & $31-50$ & $51-350$ & $350-500$ & $>500$ \\
\hline B & 10 & $11-20$ & $21-55$ & $56-80$ & $>80$ \\
\hline $\mathrm{Cu}$ & 4 & $5-9$ & $10-30$ & $31-50$ & $>50$ \\
\hline $\mathrm{Zn}$ & 10 & $11-20$ & $21-50$ & $50-75$ & $>75$ \\
\hline Mo & 0,4 & $0,5-0,9$ & $1,0-5,0$ & $5,1-10$ & $>10$ \\
\hline Al & - & - & $\angle 200$ & $201-400$ & $>400$ \\
\hline
\end{tabular}

